Article

\title{
Disclosure Frequency, Information Environment, and Cost of Capital under Regulation Fair Disclosure in the Korean Market
}

\author{
Hoshik Shim (D) \\ College of Business Administration, Kookmin University, Seoul 02707, Korea; hsshim@kookmin.ac.kr
}

Received: 30 June 2020; Accepted: 20 July 2020; Published: 21 July 2020

\begin{abstract}
Disclosure policy contributes to improve sustainable corporate information environment by mitigating information asymmetry surrounding companies. Economic theories generally support that more disclosures reduce the level of information asymmetry, increase stock liquidity, and thus decrease the costs of equity capital. However, the effect of corporate disclosure in emerging markets is not clearly predictable because of the potential information leakage prior to disclosure. Considering this issue, this study focuses on the Regulation Fair Disclosure which prohibits selective disclosure. Using the earnings-to-price ratio as a proxy of the costs of equity, the study finds that disclosure frequency is negatively related to the cost of equity capital. However, I do not find evidence that disclosure is negatively related to the implied costs of equity capital (ICOE). The results of the quintile analysis suggest that this inconsistency is attributable to the better information environment of the ICOE sample. The findings of this study have implications for disclosure regulations in emerging markets, given that the existing literature casts doubt on the effectiveness of corporate disclosure in such markets.
\end{abstract}

Keywords: regulation fair disclosure; disclosure activity; cost of equity capital; information environment

\section{Introduction}

Accounting information has been widely recognized as a tool that mitigates information asymmetry between insiders and outsiders of the company. Theories have generally suggested that information disclosed by a firm lowers the firm's cost of capital [1-3]. The basic idea is that more frequent disclosures derive greater liquidity because of the reduced information asymmetry between investors who are informed and others who are uninformed. Accordingly, investors reward firms that have high-quality disclosures with lower costs of capital. This can be viewed as a fundamental topic of the capital market, because a company's desire to reduce costs of capital through public disclosure activities is directly associated with the sustainability of the business. For example, Ok and Kim [4] suggest that investors tolerate a lower stock return from firms with better corporate social responsibility (CSR) activities, because they expect sustainable profits from those firms. Unlike the theories, however, empirical studies do not reach a consensus yet. Whether greater disclosure activity decreases cost of equity capital is still under discussion and the findings in prior studies seem to be sensitive to various firm characteristics such as firm size, analyst following, and institutional environment. In addition, samples are generally limited to large firms and especially limited to U.S. firms.

This paper examines the economic impacts of cross-sectional variation in disclosures. In detail, using Korean stock market data, the study measures the relationship between disclosure frequency and cost of equity capital. The benefits of analyzing Korean data are that the measure of voluntary disclosure covers all the listed firms and are highly credible, and that the weak legal environment 
in Korea provides a better opportunity to test the effect of disclosure [5]. Under the Regulation Fair Disclosure (Reg FD), which was adopted by the Korean government since 2002, all the material information should be disclosed on the Korea Exchange website, in order to prevent the "unfair" selection of disclosure practices. Therefore, it enables disclosure data to be collected including the timing and frequency. Meanwhile, prior studies argue that the relationship between disclosure and cost of capital is affected by the country's institutional factors, and also argue that the legal enforcement in Korea is weaker than those in other developed countries [6,7]. In this situation, using Korean data can be a good setting to investigate the effect of voluntary disclosure.

The study also explores the potential reason of mixed results in the prior literature and investigates the impact of information environment surrounding a company, based on the idea that the incremental effect of disclosure depends on the existing information environment. Considering the different information environment, various measures for cost of equity capital are used in the analysis. Using the data from 2004 to 2013, this study finds a negative relationship between the frequency of fair disclosure and the cost of equity capital proxied by the earnings-to-price ratio (E/P ratio). However, the study finds that no significant relationship exists between disclosure and the implied costs of equity capital (ICOE). The result should be carefully interpreted because analyst forecasts are essential to evaluate ICOE and analyst followings are concentrated on relatively large firms in Korea. This sample selection problem may distort the empirical results of the relationship between disclosure and cost of equity capital. To investigate this possibility, I separate samples by firm size and analyst following and I find that the disclosure effect is more pronounced in the sample with smaller size and lower analyst followings. More importantly, when I use ICOE sample, the association between E/P ratio and disclosure frequency become insignificant. This finding shows that the insignificance of relationship between ICOE and disclosure is attributable to the different sample characteristics to the $\mathrm{E} / \mathrm{P}$ ratio sample.

The research contribution to the prior literature could be considered within several aspects. First, the results support the benefits of adopting Reg FD by testing the relationship between cost of equity capital and the disclosure level. Second, this paper provides potential reasons why empirical tests show mixed results for the relationship between disclosure and cost of capital. The results imply that the existing various information channels can attenuate the effect of disclosure policy. The different information environments with respect to the sample could lead to ambiguous findings.

The following section proceeds as follows. Section 2 involves hypothesis development. Section 3 provides a description of the estimation model and empirical proxies. Section 4 shows the empirical results and the corresponding sensitivity tests. Finally, Section 5 concludes the paper.

\section{Literature Review and Hypothesis Development}

\subsection{Institutional Background}

After the enactment of Reg FD by the U.S. Securities and Exchange Commission (SEC) in 2000, Korea has also adopted the regulation since November 2002 for all listed firms to forbid unfair trading and to mitigate information asymmetry. Before the enforcement of the regulation in Korea, there was a skepticism on the effect of public disclosure due to the possibility of information leakage (pre-disclosure to selective investors). To resolve this issue, the regulation mandates company to disseminate full and prompt information to the public as soon as the related events occur. Exploiting Korean data provides a good opportunity to investigate the present research question for the following reasons. First, since Korean Reg FD is modelled after that in the U.S., both are almost identical in terms of conceptual framework. This provides a quasi-experiment to examine the effectiveness of Reg FD in emerging markets where the consequence of the regulation would be potentially greater due to higher likelihood of information leakage. Second, unlike the U.S. system, the information channel is unified to one electronic website (Korea Investor's Network for Disclosure system: KIND) of the Korea Exchange (KRX). For example, if a company plans to hold an investor relation (IR) or provide a press release, it should offer the contents on the KIND system before the events occur. If any information subject to 
fair disclosure is released during IR or press meetings, then it must be updated to the KIND system immediately after the meetings. When a company violates the regulation, it is considered to be an unfaithful disclosure company by KRX and trading is suspended. If the number of violation exceeds a threshold, the stock is delisted. In summary, all material information provided by a company should be posted on the KIND website and companies are subject to punishment if they violate the Reg FD [5]. Therefore, the voluntary disclosure data in Korea are highly trustworthy.

Another difference of Reg FD between U.S. and Korea is that, while the U.S. regulation does not prescribe the types of FD information, the following information is provided and categorized as fair disclosure under the Reg FD in Korea: estimations or forecasts of future performance, actual performance which are included in financial reports but are before submission, future business plans or management plans, and other material corporate issues. This categorization has an advantage over other measurements of voluntary disclosure in terms of the extent. For instance, prior literature adopts the AIMR database, managerial forecasts, or self-constructed measures as a disclosure proxy $[8,9]$. The AIMR database is only limited to relatively large companies, and self-constructed measures are not free from the judgements of the researcher. This limitation seems to be related with potential bias and to reduce test power. On the other hand, Reg FD data in Korea include not only managerial forecast, but also IR, press releases, press meetings, and other voluntary disclosures. That is, all the material information is disclosed on the KIND website and it allows free from bias due to the selection of specific variable.

\subsection{Disclosure and Cost of Equity Capital}

\subsubsection{Disclosure, Adverse Selection, and Agency Problem}

The fundamental theoretical backgrounds on disclosure are adverse selection and agency problem. While the efficient allocation of resource is a major concern in the economy, the information asymmetry between managers and capital providers disrupts optimal resource allocation. Since managers typically have better information than capital providers, investors request a premium for bearing information risk. For example, if capital providers do not have any information to evaluate different investment opportunities, they cannot distinguish good investment opportunities from bad ones and are likely to price them equally. Then, the market breaks [10]. If investors do not have sufficient information, this will result in the undervaluation of good prospects which means that they will demand higher returns for good stocks than the appropriate level. After allocating capital resources, the agency problem arises because capital providers cannot perfectly monitor the manager's activities. Managers seek maximization of their own benefits on the expense of maximizing the firm value [11]. Thus, if outside investors do not have sufficient information compared to what managers have, they would invest less in that firm and require more reward, which results in a higher cost of equity capital. Disclosure is a method of mitigating these problems and achieve a more efficient allocation of capital.

\subsubsection{Disclosure and Costs of Equity Capital}

A series of theoretical and empirical papers investigate the relationship between information and the cost of equity capital. Regarding the relationship between information and the cost of capital, there is a line of research suggests that a reduction in transaction costs and/or information asymmetry acts as that link [12]. Another line of research suggests the reduction in estimation risks as a link between information and cost of equity capital. Botosan [8] and Botosan and Plumlee [9] argue that disclosure quality reduces the cost of equity capital. Investors would demand fewer securities than they might have if it were not for adverse price impacts. Decrease in information revealed by trade will also encourage investors not to worry about holding a larger amount of stocks which would increase the stocks' level of demand and reduce the cost of equity capital [12]. Easley and O'Hara [3] and Easley et al. [13] and develop an asset-pricing model and provide that information risks impact the cost of capital, since uninformed investors require a higher stock return with more private information. 
Easley and $\mathrm{O}^{\prime}$ Hara [3] links information asymmetry and cost of equity capital, and is one of the foundations that state that information risk is a priced risk.

The works mentioned above indirectly link disclosure and cost of capital via adverse selection in secondary markets or liquidity. Another line of the literature encompasses investors' uncertainty about parameters, which is referred to as estimation risk, into the model and show that greater estimation risks results in a higher cost of equity capital. These studies assume that investors must estimate the parameters of returns, such as a firm's beta factor or parameters of payoff, but the estimation is uncertain. Investors rely on the available information such as historical stock return to estimate the parameters. If ample information about a firm is available, investors would be more confident in their prediction of the parameters [14-16]. Securities with less time series observations have higher betas [17].

Lambert et al. [18] in their developed model, assume that the quality of information and disclosure is a non-diversifiable risk in the multiple securities economy which is consistent with CAPM. They show that delivering high quality accounting information, reporting and disclosure decrease beta and cost of capital. Information influences the cost of equity in two ways of direct and indirect effects. Information affects the assessment of market participants in terms of firm's variance and covariance of cash flows with aggregated market cash flow (direct effect). They prove that disclosure impacts the assessed covariance of cash flow of a firm and of other firms, and that the impact in large economies is undiversifiable. In addition, Lambert et al. [18] suggest that the firm's real decision making can be affected by information. However, the direction on the cost of capital is unclear for indirect effects. For example, management rent extraction could be prohibited by disclosing information and this, in turn, could reduce cost of equity capital. However, if competitors are aware of the firm's internal information from such disclosure, they can appropriate it and benefit from the information, which would result in a higher cost of equity of the disclosing company. Lambert et al. [19] argue that disclosure reduces information asymmetry and cost of capital in imperfectly competitive markets. However, the more disclosure decreases information asymmetry and does not affect cost of capital under perfect competition in markets.

Since this paper investigates the consequence of information policy in an emerging market, it is necessary to compare the empirical findings in other developing countries, in order to develop the hypothesis. Li et al. [20] analyze the relationship between the enterprise's value creation and the carbon information disclosure of enterprises studying all companies listed in Chinese Ashare market. They find that the cost of equity capital can play as a moderator role on the positive relationship between firm value creation and carbon information disclosure. Li et al. [21] further study the media's role on the above relation and they find media reporting can improve the quality of carbon information disclosure. In addition, Li et al. [22] show how the cost of equity financing could be different depending on the areas with different marketization degrees. Supporting the previous literature, they find quantitative and qualitative carbon information disclosure have a negative relationship with the cost of equity. Fonseca et al. [23] also find a negative relationship between environment information disclosure and cost of equity capital due to the reduction of information asymmetry between different stakeholders. As discussed above, the prior literature which focuses on emerging markets generally support argument that negatively relate disclosure and cost of equity capital.

Meanwhile, not all studies find that relation using the U.S. market data. Botosan [8] reports a negative relationship between voluntary disclosure (proxied by a selfconstructed measure) and cost of equity capital. She documents the existence of a negative relationship in low analyst following companies, while the relationship is missing in high analyst following companies. Since Botosan [8] has a limitation in that the sample is confined to one industry and a certain year, Botosan and Plumlee [9] expand the sample and argue that a negative relationship between disclosure and cost of capital exists. The findings are somewhat mixed. While Botosan [8] assumes the existence of a negative relationship for low analyst following firms, Botosan and Plumlee [9] argue the existence of a positive relationship between timely voluntary disclosure and cost of capital. Graham et al.'s [24] survey on 
managers shows that $39 \%$ of mangers strongly agree that voluntary disclosure results in a decrease in cost of capital, but $22 \%$ of managers still strongly disagree. The mangers reply that high analyst following firms benefit from the decrease in cost of capital, which contradicts the findings of Botosan [8]. Healy et al. [25] also find that the cost of capital measured by realized stock returns is higher for firms with improved disclosures. Fu et al. [26] use interim reporting frequency and find that increased frequency of reporting decreases information asymmetry and cost of capital. Van Buskirk [27] does not find evidence that more frequent disclosure of monthly sales reporting lowers information asymmetry. Although the E/P ratio and realized stock returns are relatively weak proxies for cost of equity capital, the results warn researchers and regulators that cost of equity capital is not always reduced by more disclosures. Overall, there are sensitivity issues in the relationship between disclosure and cost of capital in terms of firm size, presence of financial analysts, and the institutional environment.

Compared to studies using AIMR data or selfconstructed measures, using Korean data has merits in that it covers all listed firms and is not limited to large firms or firms with analyst following. In addition, the Korean institutional environment, such as the legal system, enforcement of law, litigation risks, and market competition, are quite different from that of the U.S., and this would be worth investigating. Based on the provided discussion, the hypothesis will be stated in a directional way:

Hypothesis 1. Fair disclosure activity is negatively related with the costs of equity capital.

\section{Research Design}

\subsection{Costs of Equity Capital Measures}

Prior studies use various measures of costs of equity capital estimates to examine research questions, such as the association between firm-specific cost of equity capital and risk characteristics of firms and the relationship between a proxy of expected returns and future realized returns. However, the results of these streams of literature are mixed. In particular, studies which investigate the relation between disclosure and costs of equity capital do not reach a clear conclusion. The possible reason for this is that empirical findings depend on the measure that the researchers have chosen in their studies. In other words, proxies of costs of equity are not robust to various research settings. Given this situation in the literature, the validity of the various costs of capital estimates is unclear and it is common for similar studies to report different findings because they use different cost of equity capital measures [28].

To avoid errors in measurement used for estimating costs of equity capital, recent studies use various proxies together $[26,28]$. In general, there are two types of methods in estimating the cost of equity. The first uses the stock returns and the other uses analysts' forecasts. Return-based measures include ex-post realized returns, expected returns based on CAPM, expected returns based on the Fama-French three-factor model, and the E/P ratio. Estimates based on analysts' forecasts are often referred to as implied (or ex-ante) costs of capital. Following the prior literature, I also use the two categories of cost of capital.

First, I select E/P ratio to be the proxy of cost of equity capital. Dechow and Dichev [29], Liu et al. [30], and Francis et al. [31] report that a lower E/P ratio indicates a lower cost of equity, because investors are expected to pay more for a given dollar of earnings in case the cost of equity is lower. As a negative $E / P$ ratio (due to negative earnings) is difficult to interpret, I exclude firm year observations with negative earnings in the sample.

Second, I also estimate the implied costs of equity capital by using four individual ICOE estimates for their increased use in previous research. The four ICOEs are estimated based on Claus and Thomas [32], Gebhardt et al. [33], Gode and Mohanram [34], and Easton [35]. The ICOE estimates used by Claus and Thomas [32] and that of Gebhardt et al. [33] are based on the model of residual income valuation (RIV model). This model estimates the residual income from a dividend discount model under the assumption of the clean surplus relation. Meanwhile, the ICOEs of Gode and Mohanram [34] 
and Easton [35] are based on the model of abnormal growth valuation (OJ model), which is developed by Ohlson and Juettner-Nauroth [36]. This model relates the current price to short-term forecasted earnings, short-term growth rate, and perpetual growth rate without the assumption of the clean surplus relation. These four ICOEs are different with respect to basic assumptions of explicit forecast periods, terminal values, and the assumptions regarding short- and long-term growth rates. A detailed estimation of each ICOE is explained in Table A1 of Appendix A.

\subsection{Fair Disclosure Variables}

I obtain the frequency of fair disclosure from KIND system. The number of fair disclosures made by each firm for each calendar year is hand-collected and counted. By the securities act in Korea, unlike U.S., firms disseminate categorized fair disclosures. Types of information are classified as: A. management earnings forecasts, B. preannouncement of actual performance, $C$. future business plans or management plans, and D. other material corporate issues. Items A and B are related to quantitative disclosures, and items $\mathrm{C}$ and $\mathrm{D}$ are related to qualitative (descriptive or soft talk) disclosures. Prior studies use various disclosure measures such as AIMR scores, self-constructed measures, or disclosure frequency. It is possible to argue that disclosure frequency may not be a good proxy of disclosure quality in terms of measurement errors. Even though frequency measure includes errors, at least it seems to be a conservative proxy of disclosure quality. Given the fact that the analysis involving this measure is supported and measurement error tends to attenuate relations, this suggests that, if anything, the results provide for a conservative test.

\subsection{Research Model}

To examine whether disclosure activity is related with cost of equity capital, Equations (1) and (2) are estimated as follows:

$$
\begin{aligned}
& E / P_{i t}=\beta_{0}+\beta_{1} F D_{i t}+\beta_{2} L N V O L U M E_{i t}+\beta_{3} S I Z E_{i t}+\beta_{4} L E V_{i t}+\beta_{5} R O A_{i t} \\
& +\beta_{6} \text { LNAF }_{i t}+\beta_{7} \text { FOREIGN }_{i t-1}+\beta_{8} \text { LAROWN }_{i t-1}+\beta_{9} \text { BIG4 }_{i t} \\
& +\beta_{10} M t o B_{i t}+\beta_{11} K_{S E} E_{i t}+\gamma_{i} Y_{r} \text { Dum }+\delta_{k} I n d D u m+\varepsilon_{i t} \\
& I C O E_{i t}=\beta_{0}+\beta_{1} F D_{i t}+\beta_{2} L N V O L U M E_{i t}+\beta_{3} S I Z E_{i t}+\beta_{4} L E V_{i t}+\beta_{5} R O A_{i t} \\
& +\beta_{6} \text { BETA }_{i t}+\beta_{7} L N A F_{i t}+\beta_{8} \text { FOREIGN }_{i t-1}+\beta_{9} \text { LAROWN }_{i t-1} \\
& +\beta_{10} \text { BIG4 }_{i t}+\beta_{11} M_{t o} B_{i t}+\beta_{12} \text { KSE }_{i t}+\beta_{13} \text { DISPERSION }_{i t} \\
& +\beta_{14} \text { BIAS }_{i t}+\beta_{15} I_{\text {ICOE }} \text { AVGINDit }+\gamma_{i} \text { YrDum }+\delta_{k} I n d D u m+\varepsilon_{i t}
\end{aligned}
$$

Subscripts $i$ denotes the firm and $t$ denotes calendar years. In Equation (1), the $E / P$ ratio is used as the dependent variable for the cost of equity. I exclude observations with a negative $E / P$ ratio following prior studies [29,31]. FD denotes the frequency of fair disclosure during a year. I include LNVOLUME, which is the average daily trading volume during year $t$, to control for market liquidity since the theories posit that more disclosure reduces the level of asymmetric information, enhances liquidity of stock market, and decreases costs of equity capital. I also include additional variables which are known to affect the relationship between cost of equity capital and disclosure quality following the prior literature. Among control variables, I use ownership variables (FOREIGN and LAROWN) measured at the beginning of year $\mathrm{t}$ because these shareholders play an important role in terms of corporate governance and they are able to affect future financing and disclosure policy decisions. The definitions of all variables in the equations are explained in Table A2 of Appendix A.

In Equation (2), I use four variables of implied costs of equity capital (ICOE) and the average of the four ICOE estimates for every company (minus the riskfree rate). By following Claus and Thomas [32], Gebhardt et al. [33], Gode and Mohanram [34], and Easton [35] methods, the four individual ICOEs are estimated. The differences between Equations (1) and (2) are the sample size and control variables. In estimating ICOE, analyst forecast data are required as the proxy of future earnings (or future cash flow). Since analysts do not provide their forecast report for every firm, the sample is reduced to firms 
with analyst forecasts when using ICOE. Though analyst forecasts represent good proxies for market expectations of future earnings, these forecasts can be biased. Following prior literature [37], I include additional variables in the model of Equation (2) to control for the characteristics of analyst forecasts. First, I include analyst forecast dispersion (DISPERSION), which is measured by the log value of one plus the standard deviation of one-year-ahead forecasts scaled by lagged stock price. Second, I use analyst forecast bias (BIAS), which is calculated by the mean value of one-year-ahead analyst forecasts minus actual earnings, scaled by lagged stock price. To control for industry effect, I add the average of industry ICOE (ICOE_AVGIND) and following prior study [38], I also include BETA to control for the risk which may affect the expected returns. I expect $\beta_{1}$ to be negative both in Equations (1) and (2), supporting the hypothesis.

\section{Empirical Results}

\subsection{Sample Selection and Descriptive Statistics}

Table 1 presents the descriptive statistics for the variables included in the models. The sample selection commenced by collecting 14,835 itemized fair disclosures from 2004 to 2013 from the KIND system. After excluding missing values and outliers, a total sample of 13,850 firm year observations are recorded, of which 9149 observations have non-zero FD. Possible explanations of no-FD firms are, first, these firms have no information to voluntarily disclose. Second, they have an information event, but it is not material enough to disclose. Third, firms have important information but they decide not to disclose via fair disclosure. The third case is likely to occur when the information is negative, firms have no analyst following, or they disclosure information only to selective party. This last explanation can potentially introduce a bias that cannot be fully eliminated in measuring disclosure frequency. For the hypothesis, the sample with $E / P$ ratio (dependent variable) consists of 9096 firm year observations for 1497 firms and that with ICOE as a dependent variable has 1880 firm year observations for 473 firms. The inconsistency of number of observations in each sample is because of the availability of variables in each model. The observations consist of publicly traded companies in Korean stock market, which are KRX and KOSDAQ. I obtain financial data from KIS-VALUE, stock market data from DataGuide Pro and KCMI-SD, and analyst forecasts from FnGuide. Financial data is collected as of the fiscal year-end, while stock market data and analyst forecasts are measured as of June.

Table 1. Descriptive Statistics.

\begin{tabular}{ccccccc}
\hline \multicolumn{7}{c}{ Panel A. Descriptive Statistics of Variables in E/P Ratio Equation } \\
\hline Variables & $\mathbf{N}$ & Mean & Std. & Q1 & Median & Q3 \\
\hline E/P & 9096 & 0.125 & 0.142 & 0.048 & 0.094 & 0.158 \\
FD & 9096 & 3.082 & 3.894 & 0.000 & 2.000 & 4.000 \\
LNVOLUME & 9096 & 11.348 & 1.779 & 10.230 & 11.479 & 12.547 \\
SIZE & 9096 & 24.746 & 1.424 & 23.761 & 24.525 & 25.456 \\
LEV & 9096 & 0.539 & 0.196 & 0.373 & 0.499 & 0.697 \\
ROA & 9096 & 6.558 & 5.294 & 2.620 & 5.335 & 9.260 \\
LNAF & 9096 & 1.332 & 1.775 & 0.000 & 0.000 & 2.565 \\
FOREIGN & 9096 & 0.072 & 0.119 & 0.000 & 0.010 & 0.094 \\
LAROWN & 9096 & 0.425 & 0.160 & 0.310 & 0.415 & 0.535 \\
BIG4 & 9096 & 0.564 & 0.496 & 0.000 & 1.000 & 1.000 \\
MtoB & 9096 & 1.239 & 1.229 & 0.527 & 0.872 & 1.488 \\
KSE & 9096 & 0.452 & 0.498 & 0.000 & 0.000 & 1.000 \\
\hline
\end{tabular}


Table 1. Cont.

\begin{tabular}{|c|c|c|c|c|c|c|}
\hline \multicolumn{7}{|c|}{ Panel B. Descriptive Statistics of Variables in Implied Costs of Equity Equation } \\
\hline Variables & $\mathbf{N}$ & Mean & Std. & Q1 & Median & Q3 \\
\hline$I C O E_{-} A V G$ & 1880 & 0.104 & 0.049 & 0.067 & 0.098 & 0.132 \\
\hline$I C O E_{-} G M$ & 1880 & 0.129 & 0.067 & 0.074 & 0.118 & 0.171 \\
\hline$I C O E_{-}^{-} E S T$ & 1880 & 0.125 & 0.064 & 0.073 & 0.115 & 0.165 \\
\hline$I C O E_{-} C T$ & 1880 & 0.064 & 0.039 & 0.036 & 0.060 & 0.087 \\
\hline$I C O E_{-G L S}$ & 1880 & 0.097 & 0.043 & 0.064 & 0.089 & 0.122 \\
\hline$F \bar{D}$ & 1880 & 4.986 & 4.472 & 2.000 & 4.000 & 6.000 \\
\hline SIZE & 1880 & 26.423 & 1.433 & 25.278 & 26.150 & 27.399 \\
\hline$L E V$ & 1880 & 0.459 & 0.224 & 0.297 & 0.453 & 0.599 \\
\hline$R O A$ & 1880 & 8.147 & 6.674 & 4.050 & 7.230 & 11.925 \\
\hline BETA & 1880 & 0.973 & 0.373 & 0.710 & 0.958 & 1.222 \\
\hline LNAF & 1880 & 3.947 & 1.157 & 3.135 & 4.060 & 4.890 \\
\hline FOREIGN & 1880 & 0.157 & 0.142 & 0.041 & 0.117 & 0.239 \\
\hline LAROWN & 1880 & 0.380 & 0.142 & 0.282 & 0.372 & 0.472 \\
\hline BIG4 & 1880 & 0.736 & 0.441 & 0.000 & 1.000 & 1.000 \\
\hline$M t o B$ & 1880 & 1.784 & 1.457 & 0.841 & 1.363 & 2.133 \\
\hline$K S E$ & 1880 & 0.565 & 0.496 & 0.000 & 1.000 & 1.000 \\
\hline DISPERSION & 1880 & 0.019 & 0.022 & 0.006 & 0.013 & 0.024 \\
\hline BIAS & 1880 & -0.037 & 0.107 & -0.063 & -0.021 & 0.005 \\
\hline$I C O E_{-} A V G I N D$ & 1880 & 0.101 & 0.027 & 0.083 & 0.100 & 0.118 \\
\hline \multicolumn{7}{|c|}{ Panel C. Industry Composition } \\
\hline & & & \multicolumn{2}{|c|}{ E/P Ratio Sample } & \multicolumn{2}{|c|}{ ICOE Sample } \\
\hline \multicolumn{3}{|c|}{ Industry Sector } & $\mathrm{N}$ & Percentage & $\mathrm{N}$ & Percentage \\
\hline \multicolumn{3}{|c|}{ Food Products and Beverage } & 395 & $4.35 \%$ & 96 & $5.11 \%$ \\
\hline \multicolumn{3}{|c|}{ Chemicals and Chemical Products } & 601 & $6.61 \%$ & 123 & $6.54 \%$ \\
\hline \multicolumn{3}{|c|}{$\begin{array}{c}\text { Pharmaceuticals, Medicinal Chemical } \\
\text { Products }\end{array}$} & 552 & $6.07 \%$ & 64 & $3.41 \%$ \\
\hline \multicolumn{3}{|c|}{ Basic Metals and Metal Products } & 751 & $8.26 \%$ & 77 & $4.12 \%$ \\
\hline \multicolumn{3}{|c|}{$\begin{array}{l}\text { Electronic Components and Computer } \\
\text { Equipment }\end{array}$} & 1311 & $14.42 \%$ & 394 & $20.97 \%$ \\
\hline \multicolumn{3}{|c|}{ Other Machinery and Equipment } & 633 & $6.95 \%$ & 147 & $7.8 \%$ \\
\hline \multicolumn{3}{|c|}{$\begin{array}{c}\text { Motor Vehicles, Trailers and Transport } \\
\text { Equipment }\end{array}$} & 565 & $6.21 \%$ & 125 & $6.63 \%$ \\
\hline \multicolumn{3}{|c|}{ Construction } & 496 & $5.45 \%$ & 108 & $5.74 \%$ \\
\hline \multicolumn{3}{|c|}{ Wholesale and Retail Trade } & 601 & $6.61 \%$ & 116 & $6.19 \%$ \\
\hline \multicolumn{3}{|c|}{ Information and Communication } & 745 & $8.18 \%$ & 162 & $8.61 \%$ \\
\hline \multicolumn{3}{|c|}{$\begin{array}{c}\text { Professional, Scientific and Technical } \\
\text { Activities }\end{array}$} & 450 & $4.94 \%$ & 153 & $8.15 \%$ \\
\hline \multicolumn{3}{|c|}{ Others } & 1996 & $21.95 \%$ & 315 & $16.73 \%$ \\
\hline \multicolumn{3}{|c|}{ Total } & 9096 & $100 \%$ & 1880 & $100 \%$ \\
\hline
\end{tabular}

Notes: This table presents the statistics summary for the 9096 (and 1880) firm year observations during 2004 and 2013. The extreme values above and below $1 \%$ of each variables are excluded. See Tables A1 and A2 in Appendix A for a description of the variables.

The three panels of Table 1 present the descriptive statistics of variables included in E/P ratio equation and for ICOE equations. All the continuous variables are truncated at the 1st and 99th percentile to mitigate the outliers' effect. In Panel A, firms issue 3.08 fair disclosures on average and about one-third of the sample firm years do not issue a fair disclosure during a year. However, the frequency of disclosures increases to 4.99 and only $14.4 \%$ of the firms do not issue a fair disclosure during a certain year in the ICOE sample (Panel B). In Panel A and Panel B, the mean value of EP is 0.125 and the mean value of $I C O E_{-} A V G$ is 0.104 (the mean value of four individual ICOE vary from 0.064 to 0.129 ), which indicates that, on average, a firm's costs of equity capital is approximately $10.4 \%$ during the sample period. Panel $C$ shows industry composition of $E / P$ ratio sample and ICOE sample. 
The industry composition of sample is quite similar for most industries and in both sample, electronic components and computer equipment manufacturing companies make up the greatest portion.

Table 2 presents the correlations between the variables used in the regression models. In Panel $\mathrm{A}$, the correlation between $E / P$ and $F D$ is significantly negative, but the magnitude of the coefficient is very low (-0.07). Panel B of Table 2 shows the correlations between variables in ICOE equations. The four individual ICOEs and average ICOE show very strong correlations with each other. However, inconsistent with the E/P ratio, the correlations between each ICOE variable and disclosure frequency are positive but not significant. This conflicting result is somewhat puzzling, which led to the further examination of the relationship between disclosures and the measures of the cost of capital in multivariate analyses.

In general, the correlations between $F D$ and the control variables are by and large in line with expectations. For example, firms with high frequent information disclosure are followed by more analysts. In addition, the five instrumental variables that have been chosen are generally significantly correlated with FD. The correlation between SIZE and LNAF is also strongly positive. These correlations demonstrate the interrelations between different information environments. Regarding the ownership structure, $F D$ is negatively related to the ownership of the largest shareholder, while it is positively correlated with the foreign investors' shareholdings. Overall, the correlations in Table 2 demonstrate that the control variables used in the models are appropriate.

Table 2. Correlation Matrix.

\begin{tabular}{|c|c|c|c|c|c|c|c|c|c|c|c|}
\hline \multicolumn{12}{|c|}{ Panel A. Correlation Matrix for the Costs of Equity Capital (E/P Ratio) Equation } \\
\hline & $E / P$ & (1) & (2) & (3) & (4) & (5) & (6) & (7) & (8) & (9) & (10) \\
\hline (1) $F D$ & -0.07 & & & & & & & & & & \\
\hline (2) LNVOLUME & -0.216 & 0.257 & & & & & & & & & \\
\hline (3) SIZE & -0.206 & 0.158 & 0.197 & & & & & & & & \\
\hline (4) $L E V$ & 0.062 & -0.022 & 0.137 & 0.015 & & & & & & & \\
\hline (5) $R O A$ & 0.377 & 0.21 & 0.009 & 0.195 & -0.265 & & & & & & \\
\hline (6) $L N A F$ & -0.113 & 0.305 & 0.206 & 0.697 & -0.031 & 0.255 & & & & & \\
\hline (7) FOREIGN & -0.063 & 0.092 & -0.031 & 0.516 & -0.052 & 0.189 & 0.475 & & & & \\
\hline (8) LAROWN & 0.087 & -0.142 & -0.397 & -0.086 & -0.092 & 0.023 & -0.193 & -0.078 & & & \\
\hline (9) BIG4 & 0.007 & 0.05 & 0.006 & 0.283 & 0.033 & 0.008 & 0.216 & 0.192 & 0.007 & & \\
\hline (10) $M t o B$ & -0.309 & 0.231 & 0.287 & 0.419 & 0.092 & 0.255 & 0.287 & 0.182 & -0.123 & 0.036 & \\
\hline (11) KSE & 0.088 & -0.2 & -0.091 & 0.409 & 0.129 & -0.135 & 0.18 & 0.223 & -0.018 & 0.197 & -0.12 \\
\hline
\end{tabular}


Table 2. Cont

\begin{tabular}{|c|c|c|c|c|c|c|c|c|c|c|c|c|c|c|c|c|c|c|}
\hline \multicolumn{19}{|c|}{ Panel B. Correlation Matrix for Implied Costs of Equity (ICOE) Equation } \\
\hline & $I C O E_{A V C}$ & G (1) & (2) & (3) & $(4)$ & (5) & (6) & (7) & $(8)$ & (9) & $(10)$ & (11) & $(12)$ & (13) & $(14)$ & $(15)$ & (16) & (17) \\
\hline (1) $I C O E_{G M}$ & 0.954 & & & & & & & & & & & & & & & & & \\
\hline (2) $I C O E_{E S T}$ & 0.969 & 0.998 & & & & & & & & & & & & & & & & \\
\hline (3) $I C O E_{C T}$ & 0.776 & 0.59 & 0.632 & & & & & & & & & & & & & & & \\
\hline (4) $I C O E_{G L S}$ & 0.852 & 0.698 & 0.729 & 0.712 & & & & & & & & & & & & & & \\
\hline (5) $F D$ & 0.051 & 0.047 & 0.047 & 0.037 & 0.052 & & & & & & & & & & & & & \\
\hline (6) LNVOLUME & -0.261 & -0.228 & -0.234 & -0.254 & -0.235 & -0.028 & & & & & & & & & & & & \\
\hline (7) SIZE & 0.194 & 0.23 & 0.225 & 0.075 & 0.109 & 0.042 & 0.445 & & & & & & & & & & & \\
\hline (8) $L E V$ & -0.092 & -0.161 & -0.148 & 0.165 & -0.092 & 0.114 & -0.296 & -0.393 & & & & & & & & & & \\
\hline (9) $R O A$ & 0.148 & 0.189 & 0.179 & -0.012 & 0.115 & 0.197 & -0.035 & 0.227 & -0.048 & & & & & & & & & \\
\hline (10) LNAF & -0.244 & -0.223 & -0.228 & -0.187 & -0.236 & 0.206 & 0.476 & 0.05 & 0.018 & 0.041 & & & & & & & & \\
\hline (11) FOREIGN & -0.3 & -0.299 & -0.299 & -0.176 & -0.274 & 0.019 & 0.343 & -0.118 & 0.183 & -0.193 & 0.365 & & & & & & & \\
\hline (12) LAROWN & -0.01 & -0.031 & -0.027 & 0.044 & 0.004 & -0.054 & -0.057 & -0.091 & 0.091 & -0.186 & -0.188 & -0.09 & & & & & & \\
\hline (13) BIG4 & -0.111 & -0.081 & -0.087 & -0.121 & -0.129 & 0.025 & 0.372 & 0.156 & -0.211 & -0.009 & 0.221 & 0.132 & -0.096 & & & & & \\
\hline (14) $M t o B$ & -0.254 & -0.156 & -0.181 & -0.282 & -0.371 & 0.233 & -0.115 & 0.027 & 0.263 & 0.199 & 0.123 & 0.162 & -0.03 & -0.012 & & & & \\
\hline (15) KSE & -0.148 & -0.16 & -0.157 & -0.086 & -0.105 & -0.181 & 0.67 & 0.239 & -0.26 & -0.252 & 0.243 & 0.239 & 0.049 & 0.337 & -0.229 & & & \\
\hline (16) DISPERSION & 0.287 & 0.221 & 0.238 & 0.299 & 0.316 & -0.077 & 0.065 & 0.221 & -0.153 & 0.062 & -0.034 & -0.118 & 0.012 & -0.008 & -0.207 & 0.114 & & \\
\hline (17) BIAS & -0.248 & -0.256 & -0.257 & -0.169 & -0.175 & -0.056 & 0.16 & -0.075 & 0.09 & -0.109 & 0.07 & 0.162 & 0.032 & 0.026 & -0.029 & 0.154 & -0.082 & \\
\hline (18) $I C O E_{A V G I N D}$ & 0.563 & 0.459 & 0.483 & 0.523 & 0.617 & 0.17 & -0.157 & 0.066 & 0.071 & 0.22 & -0.023 & -0.139 & -0.101 & -0.153 & -0.192 & -0.139 & 0.191 & -0.074 \\
\hline
\end{tabular}

Notes: This table reports the Pearson correlations between variables used in the regressions. The bold figures indicate that the significance level is below $10 \%$ (two-tailed). See Tables A1 and A2 of Appendix A for a description of the variables. 


\subsection{Multivariate Analysis of the Associations between Fair Disclosure and Cost of Equity Capital}

The regression results of $E / P$ ratio on disclosure frequency are presented in Table 3 . In analyzing the relationship between disclosure and costs of equity, I include trading volume (LNVOLUME) to control the market liquidity effect on the cost of equity capital. If a higher frequency of disclosure increases market liquidity and consequently decreases the cost of capital, then the effect of market liquidity should also be considered in estimating Equation (1). Otherwise, the magnitude and significance of $F D$ will be biased upward. For comparison, I present the regression results without and with LNVOLUME in Columns (1) and (2), respectively. Since the variables differ in their scale, I show coefficients and also beta coefficients from standardized variables. In both Columns (1) and (2), the coefficient of $F D$ has negative and significant value, which is consistent with traditional disclosure theories and the hypothesis of this study. The coefficient of LNVOLUME in Column (2) is negative and significant as expected, which indicates that market liquidity is negatively related with costs of equity capital. The Chow statistic [39], which tests equality of the coefficients between two regressions, also shows that the coefficient of $F D$ in Column (1) and that in Column (2) are significantly different $(16.16, p=$ $0.0001)$. The test of equality for all other common coefficients between two regressions is not significant $(p=0.2405)$. Taken together, these tests imply that the inclusion of market liquidity variable affects the parameter of disclosure frequency, but does not affect overall parameters.

Table 3. The Impact of Disclosure on the Costs of Equity Capital (E/P Ratio).

\begin{tabular}{|c|c|c|c|c|}
\hline \multirow[t]{2}{*}{ Variables } & \multicolumn{2}{|c|}{ (1) } & \multicolumn{2}{|c|}{$(2)$} \\
\hline & Coefficient & Beta Coefficient & Coefficient & Beta Coefficient \\
\hline CONSTANT & $\begin{array}{c}0.514^{* * *} \\
(6.77)\end{array}$ & & $\begin{array}{c}0.530 * * * \\
(7.70)\end{array}$ & \\
\hline$F D$ & $\begin{array}{c}-0.002 * * * \\
(-5.70)\end{array}$ & $-0.070 * * *$ & $\begin{array}{c}-0.002 * * * \\
(-4.88)\end{array}$ & $-0.061^{* * *}$ \\
\hline LNVOLUME & & & $\begin{array}{c}-0.006^{* * *} \\
(-4.63)\end{array}$ & $-0.076^{* * *}$ \\
\hline SIZE & $\begin{array}{c}-0.021 \text { *** } \\
(-7.12)\end{array}$ & $-0.223^{* * *}$ & $\begin{array}{c}-0.019^{* * * *} \\
(-6.24)\end{array}$ & $-0.204^{* * *}$ \\
\hline$L E V$ & $\begin{array}{c}0.028^{* * *} \\
(8.84)\end{array}$ & $0.176^{* * *}$ & $\begin{array}{c}0.030 * * * \\
(9.34)\end{array}$ & $0.183^{* * *}$ \\
\hline$R O A$ & $\begin{array}{c}0.015^{* * *} \\
(23.83)\end{array}$ & $0.570^{* * *}$ & $\begin{array}{c}0.015^{* * *} \\
(23.38)\end{array}$ & $0.566^{* * *}$ \\
\hline FOREIGN & $\begin{array}{c}-0.033 * \\
(-1.70)\end{array}$ & $-0.029 *$ & $\begin{array}{c}-0.048^{* *} \\
(-2.40)\end{array}$ & $-0.043^{* *}$ \\
\hline LAROWN & $\begin{array}{l}0.014 \\
(1.04)\end{array}$ & 0.017 & $\begin{array}{l}-0.008 \\
(-0.65)\end{array}$ & -0.010 \\
\hline$L N A F$ & $\begin{array}{l}-0.001 \\
(-0.69)\end{array}$ & -0.012 & $\begin{array}{l}-0.001 \\
(-0.55)\end{array}$ & -0.010 \\
\hline MtoB & $\begin{array}{c}-0.029 * * * \\
(-12.39)\end{array}$ & $-0.267^{* * *}$ & $\begin{array}{c}-0.029 * * * \\
(-12.17)\end{array}$ & $-0.260^{* * *}$ \\
\hline BIG4 & $\begin{array}{c}0.011^{* * *} \\
(3.12)\end{array}$ & $0.040^{* * *}$ & $\begin{array}{c}0.010^{* * *} \\
(3.10)\end{array}$ & $0.039^{* * *}$ \\
\hline$K S E$ & $\begin{array}{c}0.045^{* * *} \\
(10.15)\end{array}$ & $0.166^{* * *}$ & $\begin{array}{c}0.042 * * * \\
(9.60)\end{array}$ & $0.157^{* * *}$ \\
\hline YEAR & \multicolumn{2}{|c|}{ Included } & \multicolumn{2}{|c|}{ Included } \\
\hline INDUSTRY & \multicolumn{2}{|c|}{ Included } & \multicolumn{2}{|c|}{ Included } \\
\hline Observations & \multicolumn{2}{|c|}{9096} & \multicolumn{2}{|c|}{9096} \\
\hline Adjusted $\mathrm{R}^{2}$ & \multicolumn{2}{|c|}{0.4418} & \multicolumn{2}{|c|}{0.4457} \\
\hline
\end{tabular}

Notes: This table shows the results of the regression of the $E / P$ ratio on disclosure frequency. Dummy variables of year and industry are considered but not declared for brevity. The t-statistics (in parenthesis) are adjusted by using standard errors clustered on every firm. The symbols $* * * * *$, and * refer to significant difference at the 1, 5, 10 percent level (two-tailed), respectively. Beta coefficient is estimated from the standardized variable. See Tables A1 and A2 of Appendix A for a description of the variables. 
In general, the coefficients of the control variables show expected signs. For example, a company size is negatively related with the $E / P$ ratio and a firm's leverage is positively associated with the $E / P$ ratio. However, the results show that the size of the largest shareholding has no relation with the cost of equity capital, while the coefficient of FOREIGN is negative and significant. Overall, the results in Table 3 are consistent with the main hypothesis that the frequency of disclosure is negatively related with costs of equity capital.

\subsection{Multivariate Analysis of the Associations between Fair Disclosure and Implied Costs of Equity Capital}

Table 4 shows the regression results of the relationship between disclosure frequency and the cost of equity, measured by ICOEs. As discussed earlier, the choice of proxy for the cost of equity capital could lead to different results. For this reason, I employ four implied costs of equity capital measures and their average: ICOE_GM, ICOE_EST, ICOE_CT, ICOE_GLS, and ICOE_AVG. The regression results using the average of the four individual ICOEs (ICOE_AVG) are presented in Column (1) and the results using each ICOE variable are presented in Columns (2) to (5). In Columns (1) to (5), all the coefficients of $F D$ are insignificant, which is inconsistent with the results for $E / P$ ratio. Furthermore, the results indicate that liquidity (LNVOLUME) is not associated with ICOEs. The coefficients of control variables in Table 4 are generally as expected and similar to those in Table 3 . The differences of the coefficients between the E/P ratio equation and ICOE equation appear, for example, on those of LNAF. The results show that analyst following is not related with costs of equity measured by the $E / P$ ratio. However, the relations between analyst following and ICOEs are negative and significant. In addition to existing control variables in E/P ratio equation, I include analysts' forecast dispersion and bias to control for the properties of analyst forecasts. Results presented in Table 4 show that the coefficients of DISPERSION are positively related with ICOEs and those of BIAS are negatively related with ICOEs. The results are consistent with Hwang et al. [37].

Table 4. The Impact of Disclosure on the ICOE.

\begin{tabular}{|c|c|c|c|c|c|}
\hline \multicolumn{6}{|c|}{ Panel A. Coefficients and t-Statistics } \\
\hline & (1) & (2) & (3) & (4) & (5) \\
\hline Variables & $I C O E_{-} A V G$ & $I C O E_{-} G M$ & $I C O E_{-} E S T$ & $I C O E_{-} C T$ & ICOE_GLS \\
\hline CONSTANT & $\begin{array}{c}0.268^{* * *} \\
(6.64)\end{array}$ & $\begin{array}{c}0.349^{* * * *} \\
(5.62)\end{array}$ & $\begin{array}{c}0.350^{* * *} \\
(5.83)\end{array}$ & $\begin{array}{c}0.194^{* * *} \\
(6.17)\end{array}$ & $\begin{array}{c}0.178^{* * *} \\
(5.63)\end{array}$ \\
\hline$F D$ & $\begin{array}{l}0.000 \\
(0.49)\end{array}$ & $\begin{array}{l}0.000 \\
(0.50)\end{array}$ & $\begin{array}{l}0.000 \\
(0.55)\end{array}$ & $\begin{array}{l}-0.000 \\
(-0.20)\end{array}$ & $\begin{array}{l}0.000 \\
(0.70)\end{array}$ \\
\hline LNVOLUME & $\begin{array}{l}0.001 \\
(0.48)\end{array}$ & $\begin{array}{l}0.002 \\
(0.97)\end{array}$ & $\begin{array}{l}0.002 \\
(0.86)\end{array}$ & $\begin{array}{l}0.001 \\
(0.58)\end{array}$ & $\begin{array}{l}-0.001 \\
(-1.40)\end{array}$ \\
\hline SIZE & $\begin{array}{c}-0.010^{* * *} \\
(-6.26)\end{array}$ & $\begin{array}{c}-0.013^{* * * *} \\
(-5.63)\end{array}$ & $\begin{array}{c}-0.013^{* * * *} \\
(-5.83)\end{array}$ & $\begin{array}{c}-0.007^{* * *} \\
(-5.67)\end{array}$ & $\begin{array}{c}-0.005^{* * *} \\
(-3.62)\end{array}$ \\
\hline$L E V$ & $\begin{array}{c}0.015^{* * *} \\
(5.83)\end{array}$ & $\begin{array}{c}0.021^{* * *} \\
(5.35)\end{array}$ & $\begin{array}{c}0.021^{* * *} \\
(5.50)\end{array}$ & $\begin{array}{c}0.013^{* * *} \\
(6.58)\end{array}$ & $\begin{array}{c}0.006^{* * *} \\
(3.24)\end{array}$ \\
\hline$R O A$ & $\begin{array}{l}-0.000 \\
(-0.79)\end{array}$ & $\begin{array}{c}-0.001^{* * *} \\
(-3.59)\end{array}$ & $\begin{array}{c}-0.001 \text { *** } \\
(-3.02)\end{array}$ & $\begin{array}{c}0.002 * * * \\
(7.95)\end{array}$ & $\begin{array}{l}-0.000 \\
(-1.00)\end{array}$ \\
\hline BETA & $\begin{array}{l}0.000 \\
(0.12)\end{array}$ & $\begin{array}{l}0.002 \\
(0.30)\end{array}$ & $\begin{array}{l}0.002 \\
(0.25)\end{array}$ & $\begin{array}{c}-0.006^{* *} \\
(-2.11)\end{array}$ & $\begin{array}{l}0.005 \\
(1.48)\end{array}$ \\
\hline$L N A F$ & $\begin{array}{c}-0.003 \text { ** } \\
(-2.37)\end{array}$ & $\begin{array}{l}-0.003 \\
(-1.46)\end{array}$ & $\begin{array}{l}-0.003 \\
(-1.62)\end{array}$ & $\begin{array}{c}-0.002 \text { ** } \\
(-2.28)\end{array}$ & $\begin{array}{c}-0.005^{* * *} \\
(-4.08)\end{array}$ \\
\hline FOREIGN & $\begin{array}{l}-0.007 \\
(-0.77)\end{array}$ & $\begin{array}{l}-0.010 \\
(-0.72)\end{array}$ & $\begin{array}{l}-0.009 \\
(-0.63)\end{array}$ & $\begin{array}{l}0.000 \\
(0.04)\end{array}$ & $\begin{array}{l}-0.011 \\
(-1.36)\end{array}$ \\
\hline LAROWN & $\begin{array}{l}0.010 \\
(1.11)\end{array}$ & $\begin{array}{l}0.014 \\
(0.99)\end{array}$ & $\begin{array}{l}0.014 \\
(1.01)\end{array}$ & $\begin{array}{l}0.009 \\
(1.26)\end{array}$ & $\begin{array}{l}0.004 \\
(0.46)\end{array}$ \\
\hline
\end{tabular}


Table 4. Cont.

\begin{tabular}{|c|c|c|c|c|c|}
\hline BIG4 & $\begin{array}{l}0.004 \\
(1.42)\end{array}$ & $\begin{array}{l}0.006 \\
(1.41)\end{array}$ & $\begin{array}{l}0.006 \\
(1.41)\end{array}$ & $\begin{array}{l}0.003 \\
(1.31)\end{array}$ & $\begin{array}{l}0.001 \\
(0.59)\end{array}$ \\
\hline MtoB & $\begin{array}{c}-0.006^{* * *} \\
(-5.12)\end{array}$ & $\begin{array}{c}-0.004^{* * *} \\
(-2.62)\end{array}$ & $\begin{array}{c}-0.005^{* * *} \\
(-3.35)\end{array}$ & $\begin{array}{c}-0.008^{* * *} \\
(-7.84)\end{array}$ & $\begin{array}{c}-0.007^{* * *} \\
(--5.91)\end{array}$ \\
\hline$K S E$ & $\begin{array}{l}0.002 \\
(0.52)\end{array}$ & $\begin{array}{l}0.001 \\
(0.14)\end{array}$ & $\begin{array}{l}0.001 \\
(0.21)\end{array}$ & $\begin{array}{c}0.006^{* *} \\
(2.10)\end{array}$ & $\begin{array}{l}-0.000 \\
(-0.10)\end{array}$ \\
\hline DISPERSION & $\begin{array}{c}0.258^{* * *} \\
(2.82)\end{array}$ & $\begin{array}{l}0.238 \\
(1.62)\end{array}$ & $\begin{array}{c}0.266^{*} \\
(1.93)\end{array}$ & $\begin{array}{c}0.279 * * * \\
(5.06)\end{array}$ & $\begin{array}{c}0.250 * * * \\
(4.01)\end{array}$ \\
\hline BIAS & $\begin{array}{c}-0.057^{* * *} \\
(-4.01)\end{array}$ & $\begin{array}{c}-0.076^{* * *} \\
(-3.41)\end{array}$ & $\begin{array}{c}-0.076^{* * *} \\
(-3.55)\end{array}$ & $\begin{array}{c}-0.040^{* * *} \\
(-3.81)\end{array}$ & $\begin{array}{c}-0.037^{* * *} \\
(-3.51)\end{array}$ \\
\hline$I C O E_{A} A V G I N D$ & $\begin{array}{c}0.728^{* * *} \\
(11.43)\end{array}$ & $\begin{array}{c}0.965^{* * *} \\
(10.49)\end{array}$ & $\begin{array}{c}0.952^{* * *} \\
(10.63)\end{array}$ & $\begin{array}{c}0.403^{* * *} \\
(7.60)\end{array}$ & $\begin{array}{c}0.593^{* * *} \\
(9.96)\end{array}$ \\
\hline YEAR & Included & Included & Included & Included & Included \\
\hline INDUSTRY & Included & Included & Included & Included & Included \\
\hline Observations & 1880 & 1880 & 1880 & 1880 & 1880 \\
\hline Adjusted $\mathrm{R}^{2}$ & 0.4902 & 0.3796 & 0.4030 & 0.5074 & 0.5613 \\
\hline \multicolumn{6}{|c|}{ Panel B. Beta Coefficients } \\
\hline & (1) & (2) & (3) & (4) & (5) \\
\hline Variables & $I C O E_{A} A V G$ & $I C O E_{-G M}$ & $I C O E_{-} E S T$ & $I C O E_{-C T}$ & ICOE_GLS \\
\hline$F D$ & 0.015 & 0.017 & 0.019 & -0.006 & 0.020 \\
\hline LNVOLUME & 0.017 & 0.037 & 0.033 & 0.020 & -0.048 \\
\hline SIZE & $-0.285^{* * *}$ & $-0.287 * * *$ & $-0.291^{* * *}$ & $-0.276^{* * *}$ & $-0.149^{* * *}$ \\
\hline$L E V$ & $0.235^{* * *}$ & $0.233^{* * *}$ & $0.238^{* * *}$ & $0.253^{* * *}$ & $0.106^{* * *}$ \\
\hline$R O A$ & -0.025 & $-0.122 * * *$ & $-0.101^{* * *}$ & $0.285^{* * *}$ & -0.032 \\
\hline BETA & 0.004 & 0.011 & 0.009 & $-0.062 * *$ & 0.044 \\
\hline LNAF & $-0.083^{* *}$ & -0.056 & -0.061 & $-0.073^{* *}$ & $-0.125^{* * *}$ \\
\hline FOREIGN & -0.022 & -0.022 & -0.019 & 0.001 & -0.036 \\
\hline LAROWN & 0.030 & 0.031 & 0.031 & 0.034 & 0.012 \\
\hline BIG4 & 0.039 & 0.042 & 0.041 & 0.036 & 0.015 \\
\hline MtoB & $-0.181^{* * *}$ & $-0.088^{* * *}$ & $-0.114^{* * *}$ & $-0.298^{* * *}$ & $-0.230^{* * *}$ \\
\hline$K S E$ & 0.018 & 0.005 & 0.008 & $0.072 * *$ & -0.003 \\
\hline DISPERSION & $0.121^{* * *}$ & 0.082 & 0.093 * & $0.162^{* * *}$ & $0.129 * * *$ \\
\hline BIAS & $-0.128^{* * *}$ & $-0.124^{* * *}$ & $-0.127^{* * *}$ & $-0.110^{* * *}$ & $-0.093^{* * *}$ \\
\hline$I C O E \_A V G I N D$ & $0.411^{* * *}$ & $0.398^{* * *}$ & $0.399^{* * *}$ & $0.281^{* * *}$ & $0.369 * * *$ \\
\hline
\end{tabular}

Notes: This table reports the results of regression of ICOE on disclosure frequency. Dummy variables of year and industry are considered but not declared for brevity. The t-statistics (in parenthesis) are adjusted by using standard errors clustered on every firm. The symbols ${ }^{* * *}, * *$, and $*$ refer to significant difference at the $1,5,10$ percent level (two-tailed), respectively. Beta coefficient is estimated from the standardized variable. See Tables A1 and A2 of Appendix A for a description of the variables.

Considering the results in Tables 3 and 4, I find that they partially support the hypothesis that fair disclosure frequency reduces a firm's cost of equity capital. One of the possible explanations for this inconsistency is the difference in sample distribution. As presented in Table 1, firms in ICOE sample have bigger firm size and larger analyst following on average. In addition, they disclose information more frequently, compared to firms in $E / P$ ratio sample. This difference indicates the possibility that firms in the ICOE sample have better information environments, since firm size and the number of analyst following can proxy information environment surrounding a firm. Accordingly, the disclosure impact can be diluted because investors can already obtain enough information through other channels. Without further analysis, we cannot be assured of the impact of disclosure in capital markets. To examine the validity of the tests, I conduct several robustness tests in the next section. 


\subsection{Robustness Test}

\subsubsection{The Impact of Information Environment}

To reconcile the inconsistent results between the $E / P$ ratio equation and the ICOE equation, I further examine the impact of information environment on the relationship between disclosure and the cost of equity capital. If the existing information environment surrounding a firm is good, then investors can obtain information through various information channels. In this case, disclosure would have a smaller impact (or no impact) on the costs of equity capital.

In Panel A of Table 5, I divide the sample of the $E / P$ ratio equation into small vs. large groups according to the level of information environment. I use firm size and number of analysts following as proxies for information environment. Firm year observations in small (large) firm size group are those below (above) the median value of SIZE. Firm year observations in small (large) analyst following group have zero (non-zero) analyst following. In each column, the coefficient of disclosure frequency is significantly negative. The difference between the small and large group is the magnitude of the coefficient. The magnitude (the impact) of the FD becomes larger for firms with smaller size and less analyst following. The results are similar when I separate the sample by quintile of firm size. Since about a half of the sample firms do not have analyst following, I do not use analyst following criteria in the quintile analysis. In Panel B of Table 5, the magnitude of the FD coefficient is largest in the sample of the smallest firm size (Group 1) and becomes smaller as firm size increases. In Column (5), where sample firms belong to the largest quintile, the coefficient of FD loses significance. This result is consistent with Botosan's [8] findings, which documents a negative relationship between disclosure and cost of capital only for low analyst following firms.

Table 5. The Impact of Information Environment on the Relation between Disclosure and the Costs of Equity Capital (E/P Ratio).

\begin{tabular}{|c|c|c|c|c|}
\hline \multicolumn{5}{|c|}{ Panel A. Small vs. Large (Firm Size and Analyst Following) } \\
\hline & $(1)$ & $(2)$ & (3) & $(4)$ \\
\hline Variables & Small Size & Large Size & $\begin{array}{l}\text { Small Analyst } \\
\text { Following }\end{array}$ & $\begin{array}{c}\text { Large Analyst } \\
\text { Following }\end{array}$ \\
\hline CONSTANT & $\begin{array}{c}0.832^{* * *} \\
(3.27)\end{array}$ & $\begin{array}{c}0.299 * * * \\
(5.07)\end{array}$ & $\begin{array}{c}0.701^{* * *} \\
(5.40)\end{array}$ & $\begin{array}{c}0.523^{* * *} \\
(7.97)\end{array}$ \\
\hline$F D$ & $\begin{array}{c}-0.003^{* * *} \\
(-3.92)\end{array}$ & $\begin{array}{c}-0.001^{* * *} \\
(-2.82)\end{array}$ & $\begin{array}{c}-0.003^{* * *} \\
(-4.54)\end{array}$ & $\begin{array}{c}-0.001 * \\
(-1.95)\end{array}$ \\
\hline LNVOLUME & $\begin{array}{c}-0.007^{* * *} \\
(-2.78)\end{array}$ & $\begin{array}{c}-0.004^{* * *} \\
(-3.46)\end{array}$ & $\begin{array}{c}-0.005^{* * *} \\
(-2.74)\end{array}$ & $\begin{array}{c}-0.006^{* * *} \\
(-4.79)\end{array}$ \\
\hline SIZE & $\begin{array}{c}-0.030^{* * *} \\
(-2.81)\end{array}$ & $\begin{array}{c}-0.010^{* * *} \\
(-4.16)\end{array}$ & $\begin{array}{c}-0.027^{* * *} \\
(-4.87)\end{array}$ & $\begin{array}{c}-0.017 * * * \\
(-6.17)\end{array}$ \\
\hline$L E V$ & $\begin{array}{c}0.039 * * * \\
(8.11)\end{array}$ & $\begin{array}{c}0.019^{* * *} \\
(6.71)\end{array}$ & $\begin{array}{c}0.028^{* * *} \\
(7.15)\end{array}$ & $\begin{array}{c}0.029 * * * \\
(6.46)\end{array}$ \\
\hline ROA & $\begin{array}{c}0.020^{* * *} \\
(18.03)\end{array}$ & $\begin{array}{c}0.010^{* * *} \\
(17.49)\end{array}$ & $\begin{array}{c}0.020^{* * *} \\
(18.39)\end{array}$ & $\begin{array}{c}0.010^{* * *} \\
(18.07)\end{array}$ \\
\hline FOREIGN & $\begin{array}{l}-0.016 \\
(-0.34)\end{array}$ & $\begin{array}{c}-0.056^{* * *} \\
(-3.85)\end{array}$ & $\begin{array}{l}0.008 \\
(0.18)\end{array}$ & $\begin{array}{c}-0.058^{* * *} \\
(-3.52)\end{array}$ \\
\hline LAROWN & $\begin{array}{l}-0.033 \\
(-1.45)\end{array}$ & $\begin{array}{l}0.006 \\
(0.52)\end{array}$ & $\begin{array}{l}-0.026 \\
(-1.35)\end{array}$ & $\begin{array}{l}0.003 \\
(0.20)\end{array}$ \\
\hline LNAF & $\begin{array}{l}-0.002 \\
(-0.76)\end{array}$ & $\begin{array}{l}-0.000 \\
(-0.25)\end{array}$ & & \\
\hline MtoB & $\begin{array}{c}-0.050 * * * \\
(-6.50)\end{array}$ & $\begin{array}{c}-0.023^{* * *} \\
(-11.70)\end{array}$ & $\begin{array}{c}-0.032 * * * \\
(-7.97)\end{array}$ & $\begin{array}{c}-0.024^{* * *} \\
(-10.02)\end{array}$ \\
\hline BIG4 & $\begin{array}{c}0.014^{* * *} \\
(2.87)\end{array}$ & $\begin{array}{l}0.005 \\
(1.26)\end{array}$ & $\begin{array}{c}0.007^{*} \\
(1.68)\end{array}$ & $\begin{array}{c}0.010^{* *} \\
(2.32)\end{array}$ \\
\hline KSE & $\begin{array}{c}0.045^{* * *} \\
(6.76)\end{array}$ & $\begin{array}{c}0.037^{* * *} \\
(8.11)\end{array}$ & $\begin{array}{c}0.042^{* * *} \\
(7.18)\end{array}$ & $\begin{array}{c}0.042^{* * *} \\
(7.67)\end{array}$ \\
\hline$Y E A R$ & Included & Included & Included & Included \\
\hline INDUSTRY & Included & Included & Included & Included \\
\hline Observations & 4552 & 4544 & 4671 & 4425 \\
\hline Adjusted $\mathrm{R}^{2}$ & 0.4778 & 0.4768 & 0.5044 & 0.4146 \\
\hline
\end{tabular}


Table 5. Cont.

\begin{tabular}{|c|c|c|c|c|c|}
\hline \multicolumn{6}{|c|}{ Panel B. Quintile Analysis (Firm Size) } \\
\hline & (1) & (2) & (3) & (4) & (5) \\
\hline Variables & Group 1 & Group 2 & Group 3 & Group 4 & Group 5 \\
\hline \multirow{2}{*}{ CONSTANT } & $1.797^{* * *}$ & 0.743 & $1.079^{* * *}$ & $1.056^{* * *}$ & $0.203^{* * *}$ \\
\hline & $(3.00)$ & $(1.20)$ & $(2.84)$ & $(4.35)$ & $(3.22)$ \\
\hline \multirow[t]{2}{*}{$F D$} & $-0.004^{* * *}$ & $-0.002 * *$ & $-0.002 * *$ & $-0.002^{* * *}$ & -0.000 \\
\hline & $(-2.95)$ & $(-1.97)$ & $(-1.97)$ & $(-2.89)$ & $(-0.02)$ \\
\hline \multirow{2}{*}{ LNVOLUME } & -0.005 & $-0.007^{* * *}$ & $-0.006^{* * *}$ & $-0.006^{* * *}$ & -0.001 \\
\hline & $(-1.32)$ & $(-2.90)$ & $(-3.37)$ & $(-3.82)$ & $(-0.61)$ \\
\hline \multirow[t]{2}{*}{ SIZE } & $-0.073^{* * *}$ & -0.027 & $-0.035^{* *}$ & $-0.036^{* * *}$ & $-0.004 *$ \\
\hline & $(-2.80)$ & $(-1.08)$ & $(-2.42)$ & $(-3.74)$ & $(-1.73)$ \\
\hline \multirow[t]{2}{*}{ LEV } & $0.035^{* * *}$ & $0.053^{* * *}$ & $0.033^{* * *}$ & $0.014^{* * *}$ & $0.018^{* * *}$ \\
\hline & $(5.72)$ & $(5.45)$ & $(5.52)$ & $(3.54)$ & $(5.60)$ \\
\hline \multirow[t]{2}{*}{$R O A$} & $0.028^{* * *}$ & $0.018^{* * *}$ & $0.014^{* * *}$ & $0.010^{* * *}$ & $0.008^{* * *}$ \\
\hline & (13.15) & (13.13) & (13.26) & (11.14) & (14.26) \\
\hline \multirow[t]{2}{*}{ FOREIGN } & -0.049 & 0.073 & $-0.060 * *$ & $-0.076^{* * *}$ & $-0.029^{*}$ \\
\hline & $(-1.05)$ & $(0.81)$ & $(-2.27)$ & $(-3.55)$ & $(-1.77)$ \\
\hline \multirow{2}{*}{ LAROWN } & -0.018 & -0.021 & -0.025 & 0.009 & -0.002 \\
\hline & $(-0.49)$ & $(-0.71)$ & $(-1.19)$ & $(0.53)$ & $(-0.16)$ \\
\hline \multirow[t]{2}{*}{ LNAF } & 0.000 & 0.001 & $-0.006^{* * *}$ & $-0.005^{* *}$ & $-0.004 * *$ \\
\hline & $(0.01)$ & $(0.19)$ & $(-2.83)$ & $(-2.37)$ & $(-2.15)$ \\
\hline \multirow[t]{2}{*}{ MtoB } & $-0.043^{* * *}$ & $-0.067^{* * *}$ & $-0.048^{* * *}$ & $-0.026^{* * *}$ & $-0.019^{* * *}$ \\
\hline & $(-2.90)$ & $(-6.36)$ & $(-8.04)$ & $(-7.01)$ & $(-10.05)$ \\
\hline \multirow[t]{2}{*}{ BIG4 } & 0.011 & 0.010 & $0.015^{* * *}$ & 0.002 & 0.001 \\
\hline & $(1.29)$ & $(1.32)$ & $(2.69)$ & $(0.51)$ & $(0.18)$ \\
\hline \multirow[t]{2}{*}{ KSE } & $0.058 * * *$ & $0.034^{* * *}$ & $0.035^{* * *}$ & $0.038^{* * *}$ & $0.026^{* * *}$ \\
\hline & $(5.23)$ & $(4.24)$ & $(5.32)$ & $(5.63)$ & $(4.62)$ \\
\hline YEAR & Included & Included & Included & Included & Included \\
\hline \multirow{2}{*}{\multicolumn{6}{|c|}{$\begin{array}{l}\text { INDUSTRY } \\
\text { Mean Value of }\end{array}$}} \\
\hline & & & & & \\
\hline SIZE (in billion & 11.191 & 12.020 & 46.193 & 95.547 & 1018.371 \\
\hline \multicolumn{6}{|l|}{ KRW) } \\
\hline Observations & 1832 & 1829 & 1794 & 1801 & 1840 \\
\hline Adjusted $R^{2}$ & 0.5236 & 0.4752 & 0.5561 & 0.4865 & 0.4905 \\
\hline
\end{tabular}

Notes: This Table shows the results of regressions of $E / P$ ratio on disclosure frequency according to the level of information environment, which is proxied by SIZE and LNAF. In Panel A, sample for E/P ratio equation is divided into small vs. large group. Firm year observations in small (large) size group are those below (above) the median value of SIZE. Firm year observations in small (large) analyst following group have zero (non-zero) analyst following. In Panel B, Group 1 indicates the sample with bottom (smallest) quintile of firm size, and Group 5 indicates the sample with top (largest) quintile of firm size. Both year and industry dummies are considered in the regressions but not declared for brevity. The t-statistics (in parenthesis) are adjusted by using standard errors clustered on every firm. The symbols ${ }^{* *},{ }^{* *}$, and ${ }^{*}$ refer to significant difference at the 1, 5, 10 percent level (two-tailed), respectively. See Tables A1 and A2 of Appendix A for a description of the variables.

Next, I also separate the sample for ICOE equation according to the information environment. Firm year observations in small (large) group are those below (above) the median value of each proxy of information environment (SIZE and $L N A F$ ). Unlike the results with $E / P$ ratio sample, the results in Table 6 (Panel A, B and C) show that disclosure is not related with the level of implied costs of equity capital (ICOE), and that firm size and the number of analyst following does not affect the relation for the ICOE sample. The results are in line with the findings in Table 4. Though the results indicate an insignificant relationship between disclosure frequency and the ICOE, this can be reconciled with the results using $E / P$ ratio sample. As discussed earlier, the samples for ICOE equations have much larger firm size, more analyst followings, and issue more disclosures than the sample for $E / P$ ratio equation. As firms for which ICOE can be estimated already have a better information environment, compared to the population, the incremental impact of disclosure can be small or immaterial in these firms. 
Table 6. The Impact of Information Environment on the Relationship between Disclosure and the ICOE.

\begin{tabular}{|c|c|c|c|c|}
\hline \multicolumn{5}{|c|}{ Panel A. Small vs. Large (Firm Size and Analyst Following) } \\
\hline \multirow[b]{2}{*}{ Variables } & \multicolumn{2}{|c|}{ SIZE } & \multicolumn{2}{|c|}{ ANALYST FOLLOWING } \\
\hline & SMALL & LARGE & SMALL & LARGE \\
\hline \multirow[t]{2}{*}{ CONSTANT } & $0.2502 * *$ & $0.2669 * * *$ & $0.2827^{* * *}$ & $0.2178^{* * *}$ \\
\hline & $(2.55)$ & $(4.56)$ & $(4.04)$ & $(5.34)$ \\
\hline \multirow[t]{2}{*}{$F D$} & -0.0005 & 0.0006 & 0.0005 & 0.0000 \\
\hline & $(-1.06)$ & $(1.19)$ & $(0.85)$ & $(0.01)$ \\
\hline \multirow[t]{2}{*}{ LNVOLUME } & 0.0019 & 0.0006 & 0.0022 & -0.0010 \\
\hline & $(0.85)$ & $(0.43)$ & $(1.45)$ & $(-0.74)$ \\
\hline \multirow[t]{2}{*}{ SIZE } & $-0.0098^{* *}$ & $-0.0091^{* * *}$ & $-0.0119^{* * *}$ & $-0.0067^{* * *}$ \\
\hline & $(-2.52)$ & $(-4.18)$ & $(-4.61)$ & $(-3.91)$ \\
\hline \multirow[t]{2}{*}{$L E V$} & $0.0142^{* * *}$ & $0.0170 * * *$ & $0.0169^{* * *}$ & $0.0131^{* * *}$ \\
\hline & (3.34) & $(5.50)$ & $(4.47)$ & $(4.20)$ \\
\hline \multirow[t]{2}{*}{$R O A$} & -0.0003 & 0.0002 & -0.0005 & 0.0003 \\
\hline & $(-1.08)$ & $(0.42)$ & $(-1.60)$ & $(0.93)$ \\
\hline \multirow[t]{2}{*}{ BETA } & -0.0026 & 0.0004 & 0.0019 & -0.0051 \\
\hline & $(-0.41)$ & $(0.06)$ & $(0.33)$ & $(-1.06)$ \\
\hline \multirow[t]{2}{*}{$L N A F$} & -0.0032 & -0.0035 & 0.0002 & -0.0015 \\
\hline & $(-1.64)$ & $(-1.62)$ & $(0.11)$ & $(-0.40)$ \\
\hline \multirow[t]{2}{*}{ FOREIGN } & -0.0191 & -0.0006 & -0.0036 & -0.0113 \\
\hline & $(-1.25)$ & $(-0.05)$ & $(-0.23)$ & $(-1.10)$ \\
\hline \multirow[t]{2}{*}{ LAROWN } & 0.0081 & 0.0131 & 0.0160 & 0.0016 \\
\hline & $(0.67)$ & $(0.99)$ & $(1.32)$ & $(0.15)$ \\
\hline \multirow[t]{2}{*}{ BIG4 } & 0.0050 & 0.0025 & 0.0045 & 0.0043 \\
\hline & $(1.46)$ & $(0.44)$ & $(1.22)$ & $(0.98)$ \\
\hline \multirow[t]{2}{*}{$M t o B$} & -0.0024 & $-0.0103^{* * *}$ & $-0.0067^{* * *}$ & $-0.0058^{* * *}$ \\
\hline & $(-1.56)$ & $(-6.14)$ & $(-4.16)$ & $(-4.08)$ \\
\hline \multirow[t]{2}{*}{ KSE } & 0.0030 & 0.0028 & 0.0050 & -0.0031 \\
\hline & $(0.68)$ & (0.59) & $(1.02)$ & $(-0.73)$ \\
\hline \multirow[t]{2}{*}{ DISPERSION } & 0.2958 * & $0.2169^{* *}$ & 0.1827 * & $0.5334^{* * *}$ \\
\hline & (1.82) & $(2.26)$ & (1.82) & $(4.50)$ \\
\hline \multirow[t]{2}{*}{ BIAS } & $-0.0470 *$ & $-0.0636^{* * *}$ & $-0.0432 * *$ & $-0.0552^{* * *}$ \\
\hline & $(-1.94)$ & $(-3.75)$ & $(-2.08)$ & $(-3.53)$ \\
\hline \multirow[t]{2}{*}{$I C O E_{-} A V G I N D$} & $0.8489^{* * *}$ & $0.6090 * * *$ & $0.8487^{* * *}$ & $0.6233^{* * *}$ \\
\hline & $(8.23)$ & $(7.41)$ & $(8.42)$ & $(9.91)$ \\
\hline$Y E A R$ & Included & Included & Included & Included \\
\hline INDUSTRY & Included & Included & Included & Included \\
\hline Observations & 940 & 940 & 941 & 939 \\
\hline Adjusted $\mathrm{R}^{2}$ & 0.3895 & 0.5555 & 0.4222 & 0.5364 \\
\hline
\end{tabular}


Table 6. Cont.

\begin{tabular}{|c|c|c|c|c|c|}
\hline \multicolumn{6}{|c|}{ Panel B. Quintile Analysis (Firm Size) } \\
\hline Variables & (1) Group 1 & (2) Group 2 & (3) Group 3 & (4) Group 4 & (5) Group 5 \\
\hline \multirow[t]{2}{*}{ CONSTANT } & 0.3477 & -0.1339 & 0.3673 & 0.3099 & $0.2835 * *$ \\
\hline & $(1.57)$ & $(-0.40)$ & $(1.44)$ & $(1.54)$ & $(2.03)$ \\
\hline \multirow[t]{2}{*}{$F D$} & -0.0005 & -0.0008 & -0.0005 & $0.0016^{* * *}$ & -0.0002 \\
\hline & $(-0.62)$ & $(-1.47)$ & $(-0.90)$ & $(2.95)$ & $(-0.26)$ \\
\hline \multirow[t]{2}{*}{ LNVOLUME } & 0.0018 & 0.0011 & 0.0006 & $-0.0026^{*}$ & 0.0049 \\
\hline & $(0.42)$ & $(0.32)$ & $(0.26)$ & $(-1.95)$ & $(1.60)$ \\
\hline \multirow[t]{2}{*}{ SIZE } & -0.0138 & 0.0060 & -0.0123 & -0.0103 & $-0.0120 * *$ \\
\hline & $(-1.56)$ & $(0.46)$ & $(-1.29)$ & $(-1.37)$ & $(-2.53)$ \\
\hline \multirow[t]{2}{*}{$L E V$} & $0.0272^{* * *}$ & $0.0141^{* *}$ & 0.0050 & $0.0226^{* * *}$ & $0.0177 * * *$ \\
\hline & $(3.40)$ & $(2.23)$ & (1.06) & $(4.80)$ & (4.15) \\
\hline \multirow[t]{2}{*}{$R O A$} & -0.0003 & -0.0000 & $-0.0012^{* *}$ & 0.0001 & 0.0007 \\
\hline & $(-0.72)$ & $(-0.06)$ & $(-2.09)$ & $(0.09)$ & $(0.96)$ \\
\hline \multirow[t]{2}{*}{ BETA } & -0.0117 & 0.0046 & -0.0011 & 0.0089 & -0.0026 \\
\hline & $(-1.23)$ & $(0.38)$ & $(-0.12)$ & $(0.81)$ & $(-0.32)$ \\
\hline \multirow[t]{2}{*}{ LNAF } & -0.0000 & -0.0055 & -0.0026 & -0.0031 & -0.0012 \\
\hline & $(-0.01)$ & $(-1.53)$ & $(-1.12)$ & $(-0.95)$ & $(-0.33)$ \\
\hline \multirow[t]{2}{*}{ FOREIGN } & -0.0141 & -0.0298 & -0.0322 & -0.0124 & $0.0442 * *$ \\
\hline & $(-0.56)$ & $(-1.31)$ & $(-1.47)$ & $(-0.69)$ & $(2.01)$ \\
\hline \multirow[t]{2}{*}{ LAROWN } & 0.0134 & -0.0066 & 0.0196 & 0.0121 & 0.0332 \\
\hline & $(0.73)$ & $(-0.31)$ & $(1.03)$ & $(0.94)$ & $(1.28)$ \\
\hline \multirow[t]{2}{*}{ BIG4 } & 0.0085 & 0.0058 & 0.0034 & 0.0030 & -0.0108 \\
\hline & (1.45) & $(1.03)$ & $(0.63)$ & $(0.44)$ & $(-0.86)$ \\
\hline \multirow[t]{2}{*}{$M t o B$} & $-0.0043^{*}$ & -0.0031 & -0.0027 & $-0.0100^{* * *}$ & $-0.0108^{* * *}$ \\
\hline & $(-1.94)$ & $(-1.11)$ & $(-0.89)$ & $(-2.96)$ & $(-4.57)$ \\
\hline \multirow[t]{2}{*}{ KSE } & 0.0044 & -0.0030 & 0.0055 & -0.0012 & \\
\hline & $(0.49)$ & $(-0.48)$ & $(0.89)$ & $(-0.20)$ & \\
\hline \multirow[t]{2}{*}{ DISPERSION } & 0.1876 & 0.2352 & $0.4866^{* * *}$ & 0.1832 & 0.1596 \\
\hline & $(0.76)$ & $(1.21)$ & $(4.54)$ & $(0.91)$ & (1.46) \\
\hline \multirow[t]{2}{*}{$B I A S$} & $-0.1124^{* *}$ & -0.0275 & -0.0378 & -0.0242 & $-0.0667^{* * *}$ \\
\hline & $(-2.25)$ & $(-0.76)$ & $(-1.61)$ & $(-0.79)$ & $(-4.22)$ \\
\hline \multirow[t]{2}{*}{$I C O E_{-} A V G I N D$} & $0.7627^{* * *}$ & $0.8611^{* * *}$ & $0.5398^{* * *}$ & $0.7667^{* * *}$ & $0.7146^{* * *}$ \\
\hline & $(4.78)$ & $(4.82)$ & $(4.35)$ & (6.23) & $(4.75)$ \\
\hline$Y E A R$ & Included & Included & Included & Included & Included \\
\hline \multirow{4}{*}{$\begin{array}{l}\text { INDUSTRY } \\
\text { Mean Value } \\
\text { of SIZE } \\
\text { (in billion } \\
\text { KRW) }\end{array}$} & Included & Included & Included & Included & Included \\
\hline & & & & & \\
\hline & 79.263 & 132.846 & 215.707 & 547.668 & 2441.728 \\
\hline & & & & & \\
\hline \multirow{2}{*}{$\begin{array}{l}\text { Observations } \\
\text { Adjusted } \\
\mathrm{R}^{2}\end{array}$} & 376 & 378 & 376 & 375 & 375 \\
\hline & 0.4226 & 0.3469 & 0.4870 & 0.5328 & 0.5718 \\
\hline
\end{tabular}


Table 6. Cont.

\begin{tabular}{|c|c|c|c|c|c|}
\hline \multicolumn{6}{|c|}{ Panel C. Quintile Analysis (Analyst Following) } \\
\hline Variables & (1) Group 1 & (2) Group 2 & (3) Group 3 & (4) Group 4 & (5) Group 5 \\
\hline CONSTANT & 0.2079 * & 0.1199 & $0.4047^{* * *}$ & $0.3128^{* * *}$ & $0.2075^{* * *}$ \\
\hline$F D$ & $\begin{array}{l}0.0005 \\
(0.47)\end{array}$ & $\begin{array}{l}0.0012 \\
(1.55)\end{array}$ & $\begin{array}{c}-0.0005 \\
(-0.77)\end{array}$ & $\begin{array}{c}-0.0006 \\
(-1.27)\end{array}$ & $\begin{array}{c}0.0006 \text { * } \\
(1.76)\end{array}$ \\
\hline LNVOLUME & $\begin{array}{c}0.0070^{* *} \\
(2.39)\end{array}$ & $\begin{array}{l}0.0035 \\
(1.35)\end{array}$ & $\begin{array}{c}-0.0007 \\
(-0.28)\end{array}$ & $\begin{array}{c}-0.0026 \\
(-1.20)\end{array}$ & $\begin{array}{c}0.0007 \\
(0.37)\end{array}$ \\
\hline SIZE & $\begin{array}{c}-0.0098^{* *} \\
(-2.21)\end{array}$ & $\begin{array}{l}-0.0063 \\
(-1.45)\end{array}$ & $\begin{array}{c}-0.0123^{* * * *} \\
(-2.67)\end{array}$ & $\begin{array}{c}-0.0088^{* * * *} \\
(-3.56)\end{array}$ & $\begin{array}{c}-0.0076^{* * * *} \\
(-3.47)\end{array}$ \\
\hline$L E V$ & $\begin{array}{c}0.0145^{* *} \\
(2.04)\end{array}$ & $\begin{array}{c}0.0137^{* *} \\
(2.46)\end{array}$ & $\begin{array}{c}0.0162^{* *} \\
(2.46)\end{array}$ & $\begin{array}{c}0.0174^{* * *} \\
(4.30)\end{array}$ & $\begin{array}{c}0.0128 * * * \\
(3.44)\end{array}$ \\
\hline$R O A$ & $\begin{array}{c}0.0000 \\
(0.04)\end{array}$ & $\begin{array}{c}-0.0009^{*} \\
(-1.92)\end{array}$ & $\begin{array}{l}-0.0006 \\
(-1.46)\end{array}$ & $\begin{array}{c}0.0009 * \\
(1.77)\end{array}$ & $\begin{array}{l}-0.0001 \\
(-0.36)\end{array}$ \\
\hline BETA & $\begin{array}{l}-0.0107 \\
(-1.12)\end{array}$ & $\begin{array}{c}0.0045 \\
(0.46)\end{array}$ & $\begin{array}{l}-0.0088 \\
(-1.11)\end{array}$ & $\begin{array}{c}-0.0036 \\
(-0.39)\end{array}$ & $\begin{array}{l}-0.0062 \\
(-0.86)\end{array}$ \\
\hline$L N A F$ & $\begin{array}{c}0.0033 \\
(0.79)\end{array}$ & $\begin{array}{l}-0.0010 \\
(-0.07)\end{array}$ & $\begin{array}{l}-0.0169 \\
(-1.43)\end{array}$ & $\begin{array}{l}-0.0066 \\
(-0.58)\end{array}$ & $\begin{array}{c}0.0003 \\
(0.04)\end{array}$ \\
\hline FOREIGN & $\begin{array}{l}0.0133 \\
(0.55)\end{array}$ & $\begin{array}{c}-0.0106 \\
(-0.43)\end{array}$ & $\begin{array}{l}-0.0231 \\
(-1.02)\end{array}$ & $\begin{array}{l}-0.0045 \\
(-0.25)\end{array}$ & $\begin{array}{l}-0.0088 \\
(-0.77)\end{array}$ \\
\hline LAROWN & $\begin{array}{l}0.0120 \\
(0.57)\end{array}$ & $\begin{array}{c}0.0323 \\
(1.52)\end{array}$ & $\begin{array}{c}0.0174 \\
(1.04)\end{array}$ & $\begin{array}{l}-0.0099 \\
(-0.72)\end{array}$ & $\begin{array}{c}0.0111 \\
(0.58)\end{array}$ \\
\hline BIG4 & $\begin{array}{c}0.0020 \\
(0.36)\end{array}$ & $\begin{array}{c}0.0052 \\
(0.84)\end{array}$ & $\begin{array}{c}0.0041 \\
(0.69)\end{array}$ & $\begin{array}{c}0.0096 \\
(1.44)\end{array}$ & $\begin{array}{c}0.0021 \\
(0.34)\end{array}$ \\
\hline MtoB & $\begin{array}{c}-0.0080 * \\
(-1.92)\end{array}$ & $\begin{array}{c}-0.0045^{*} \\
(-1.97)\end{array}$ & $\begin{array}{c}-0.0056^{* * *} \\
(-2.76)\end{array}$ & $\begin{array}{c}-0.0075^{* * *} \\
(-2.91)\end{array}$ & $\begin{array}{c}-0.0041^{* * *} \\
(-2.93)\end{array}$ \\
\hline KSE & $\begin{array}{c}0.0043 \\
(0.52)\end{array}$ & $\begin{array}{c}0.0039 \\
(0.54)\end{array}$ & $\begin{array}{l}-0.0036 \\
(-0.50)\end{array}$ & $\begin{array}{c}-0.0011 \\
(-0.16)\end{array}$ & $\begin{array}{l}-0.0024 \\
(-0.45)\end{array}$ \\
\hline DISPERSION & $\begin{array}{c}0.0846 \\
(0.83)\end{array}$ & $\begin{array}{c}0.2661^{* * *} \\
(2.67)\end{array}$ & $\begin{array}{c}0.4564^{* * *} \\
(3.00)\end{array}$ & $\begin{array}{c}0.5185^{* *} \\
(2.30)\end{array}$ & $\begin{array}{c}0.7093^{* * *} \\
(5.32)\end{array}$ \\
\hline$B I A S$ & $\begin{array}{c}-0.1160^{* * *} \\
(-3.30)\end{array}$ & $\begin{array}{l}-0.0226 \\
(-0.97)\end{array}$ & $\begin{array}{c}0.0208 \\
(0.64)\end{array}$ & $\begin{array}{c}-0.0620 * * * \\
(-2.90)\end{array}$ & $\begin{array}{c}-0.0834^{* * * *} \\
(-3.37)\end{array}$ \\
\hline$I C O E_{A} A V G I N D$ & $\begin{array}{c}0.6393 * * * \\
(3.85)\end{array}$ & $\begin{array}{c}0.8206^{* * *} \\
(5.25)\end{array}$ & $\begin{array}{c}0.9378^{* * *} \\
(6.85)\end{array}$ & $\begin{array}{c}0.6376^{* * *} \\
(5.82)\end{array}$ & $\begin{array}{c}0.5566^{* * * *} \\
(6.66)\end{array}$ \\
\hline YEAR & Included & Included & Included & Included & Included \\
\hline INDUSTRY & Included & Included & Included & Included & Included \\
\hline Observations & 362 & 387 & 379 & 376 & 376 \\
\hline $\begin{array}{l}\text { Adjusted } \\
\mathrm{R}^{2}\end{array}$ & 0.4644 & 0.3699 & 0.5067 & 0.5339 & 0.5965 \\
\hline
\end{tabular}

Notes: This Table shows the results of regressions of ICOE on disclosure frequency according to the level of information environment, which is proxied by SIZE and LNAF. In Panel A, sample for ICOE equation is divided into small vs. large group. Firm year observations in small (large) group are those below (above) the median value of each proxy of information environment (SIZE and LNAF). In Panel B, Group 1 indicates the sample with bottom (smallest) quintile of firm size, and Group 5 indicates the sample with top (largest) quintile of firm size. In Panel C, Group 1 indicates the sample with bottom (smallest) quintile of analyst following, and Group 5 indicates the sample with top (largest) quintile of analyst following. Both year and industry dummies are considered in the regressions but not declared and the result using ICOE_AVG as a dependent variable is only reported for brevity. The results with other ICOEs are similar. The t-statistics (in parenthesis) are adjusted by using standard errors clustered on every firm. The symbols ${ }^{* * *},{ }^{* *}$, and ${ }^{*}$ refer to significant difference at the 1, 5, 10 percent level (two-tailed), respectively. See Tables A1 and A2 of Appendix A for a description of the variables.

To validate this finding, I also regress the E/P ratio on disclosure frequency using the ICOE sample, which seems to be in a better information environment. If the result using $E / P$ ratio shows a negative and significant relation, then the insignificant relation between $F D$ and ICOEs can be attributed to the measurement errors in ICOEs. However, if the relation is also insignificant, then it can be attributed to the different distribution between two samples. The results are presented in Table 7. First, the result in Column (1) of Panel A shows that the E/P ratio has no relationship with disclosure frequency for the 
total sample of ICOE. When I separate the sample by quintile of firm size, five groups do not show a consistent pattern as firm size increases (or decreases). For group 3, results indicate that disclosure frequency and E/P ratio are negatively related. However, for group 4, which is just beside group 3, the coefficient of $F D$ shows a significant positive sign. The results using the sample divided by the quintile of analyst following also show inconsistent and insignificant relations between disclosure and the cost of capital (except for the third quintile sample). The finding in Table 7 also suggests that the sample of ICOE equation has a different distribution, compared to the total sample, and that better information environments mitigate the impact of disclosure on costs of equity capital.

Table 7. The Impact of Disclosure on the Costs of Equity Capital (E/P Ratio): Using ICOE Sample.

\begin{tabular}{|c|c|c|c|c|c|c|}
\hline \multicolumn{7}{|c|}{ Panel A. Quintile Analysis (SIZE) } \\
\hline \multirow[b]{2}{*}{ Variables } & (1) & \multirow{2}{*}{$\begin{array}{c}(2) \\
\text { GROUP } 1\end{array}$} & \multirow{2}{*}{$\begin{array}{c}(3) \\
\text { GROUP } 2\end{array}$} & \multirow{2}{*}{$\begin{array}{c}(4) \\
\text { GROUP } 3\end{array}$} & \multirow{2}{*}{$\begin{array}{c}(5) \\
\text { GROUP } 4\end{array}$} & \multirow{2}{*}{$\begin{array}{c}(6) \\
\text { GROUP } 5\end{array}$} \\
\hline & TOTAL & & & & & \\
\hline \multirow[t]{2}{*}{ CONSTANT } & $0.4054^{* * *}$ & 0.7774 * & 0.9742 & 0.2779 & 0.3295 & 0.0799 \\
\hline & (6.01) & (1.92) & (1.52) & $(0.74)$ & $(0.95)$ & $(0.70)$ \\
\hline \multirow[t]{2}{*}{$F D$} & -0.0002 & -0.0005 & 0.0003 & $-0.0017^{* *}$ & 0.0017 * & 0.0013 \\
\hline & $(-0.47)$ & $(-0.48)$ & $(0.35)$ & $(-2.07)$ & $(1.73)$ & $(1.40)$ \\
\hline \multirow[t]{2}{*}{ LNVOLUME } & $-0.0027^{*}$ & $-0.0079^{* *}$ & -0.0009 & 0.0024 & -0.0054 * & 0.0008 \\
\hline & $(-1.75)$ & $(-2.17)$ & $(-0.21)$ & $(0.65)$ & $(-1.74)$ & $(0.42)$ \\
\hline \multirow[t]{2}{*}{$S I Z E$} & $-0.0101 * * *$ & -0.0238 & -0.0319 & -0.0096 & -0.0034 & -0.0023 \\
\hline & $(-4.13)$ & $(-1.41)$ & $(-1.29)$ & $(-0.68)$ & $(-0.25)$ & $(-0.52)$ \\
\hline \multirow[t]{2}{*}{$L E V$} & $0.0209^{* * *}$ & $0.0287^{* *}$ & $0.0417^{* * *}$ & $0.0259 * * *$ & $0.0145^{* *}$ & $0.0091 * *$ \\
\hline & $(4.94)$ & $(2.31)$ & (3.67) & (3.11) & $(2.57)$ & $(2.12)$ \\
\hline \multirow[t]{2}{*}{$R O A$} & $0.0077^{* * *}$ & $0.0095^{* * *}$ & $0.0098^{* * *}$ & $0.0066^{* * *}$ & $0.0068^{* * *}$ & $0.0083^{* * *}$ \\
\hline & (14.04) & (9.99) & $(6.54)$ & (6.49) & $(8.74)$ & (5.30) \\
\hline \multirow[t]{2}{*}{ FOREIGN } & $-0.0356^{* *}$ & $-0.0772 * *$ & -0.0119 & -0.0312 & -0.0495 & -0.0196 \\
\hline & $(-2.43)$ & $(-2.00)$ & $(-0.37)$ & $(-1.03)$ & $(-1.61)$ & $(-0.82)$ \\
\hline \multirow[t]{2}{*}{ LAROWN } & 0.0134 & 0.0082 & 0.0233 & 0.0435 * & -0.0018 & -0.0090 \\
\hline & $(0.90)$ & $(0.27)$ & $(0.54)$ & $(1.81)$ & $(-0.06)$ & $(-0.37)$ \\
\hline \multirow[t]{2}{*}{$L N A F$} & -0.0023 & -0.0004 & -0.0034 & 0.0006 & -0.0043 & -0.0006 \\
\hline & $(-1.17)$ & $(-0.10)$ & $(-0.77)$ & $(0.17)$ & $(-1.09)$ & $(-0.15)$ \\
\hline \multirow[t]{2}{*}{ MtoB } & $-0.0237^{* * *}$ & $-0.0560^{* * *}$ & $-0.0464^{* * *}$ & $-0.0225^{* * *}$ & $-0.0236^{* * *}$ & $-0.0188^{* * *}$ \\
\hline & $(-10.27)$ & $(-4.37)$ & $(-5.41)$ & $(-5.77)$ & $(-5.13)$ & $(-6.22)$ \\
\hline \multirow[t]{2}{*}{ BIG4 } & 0.0038 & 0.0114 & 0.0071 & 0.0078 & $0.0148^{*}$ & -0.0067 \\
\hline & $(0.80)$ & $(1.56)$ & $(0.65)$ & $(0.96)$ & (1.95) & $(-0.47)$ \\
\hline \multirow[t]{2}{*}{ KSE } & $0.0324^{* * *}$ & 0.0245 * & $0.0342 * * *$ & $0.0253 * *$ & $0.0202 * *$ & 0.0179 \\
\hline & $(5.32)$ & (1.88) & $(2.73)$ & $(2.44)$ & $(2.21)$ & (1.15) \\
\hline$Y E A R$ & Included & Included & Included & Included & Included & Included \\
\hline INDUSTRY & Included & Included & Included & Included & Included & Included \\
\hline $\begin{array}{l}\text { Mean Value } \\
\text { of SIZE (in } \\
\text { billion KRW) }\end{array}$ & 711.163 & 79.313 & 134.7108 & 221.608 & 564.597 & 2500.58 \\
\hline Observations & 1782 & 355 & 357 & 357 & 357 & 356 \\
\hline Adjusted $\mathrm{R}^{2}$ & 0.5203 & 0.6297 & 0.5035 & 0.5705 & 0.4644 & 0.6227 \\
\hline
\end{tabular}


Table 7. Cont.

\begin{tabular}{|c|c|c|c|c|c|}
\hline \multicolumn{6}{|c|}{ Panel B. Quintile Analysis (Analyst Following) } \\
\hline & (1) & (2) & (3) & (4) & (5) \\
\hline Variables & GROUP 1 & GROUP 2 & GROUP 3 & GROUP 4 & GROUP 5 \\
\hline \multirow[t]{2}{*}{ CONSTANT } & $0.3808^{* *}$ & $0.6518 * * *$ & $0.4058^{* * *}$ & 0.1590 & 0.1296 \\
\hline & $(2.24)$ & $(4.55)$ & (2.82) & $(1.00)$ & $(1.32)$ \\
\hline \multirow[t]{2}{*}{$F D$} & -0.0018 & -0.0012 & $-0.0019 *$ & 0.0004 & 0.0006 \\
\hline & $(-1.13)$ & $(-1.01)$ & $(-1.76)$ & $(0.44)$ & $(0.80)$ \\
\hline \multirow[t]{2}{*}{ LNVOLUME } & -0.0039 & 0.0009 & -0.0045 & -0.0050 & 0.0031 \\
\hline & $(-1.02)$ & $(0.29)$ & $(-1.47)$ & $(-1.46)$ & $(0.90)$ \\
\hline \multirow[t]{2}{*}{ SIZE } & -0.0104 & $-0.0207^{* * *}$ & $-0.0136^{* *}$ & -0.0038 & -0.0038 \\
\hline & $(-1.59)$ & $(-3.50)$ & $(-2.43)$ & $(-0.77)$ & $(-1.04)$ \\
\hline \multirow[t]{2}{*}{ LEV } & $0.0306^{* * *}$ & $0.0152 *$ & $0.0126^{* *}$ & $0.0287^{* * *}$ & $0.0180 * * *$ \\
\hline & $(3.17)$ & $(1.82)$ & (1.99) & $(3.41)$ & $(3.63)$ \\
\hline \multirow[t]{2}{*}{$R O A$} & $0.0099^{* * *}$ & $0.0071^{* * *}$ & $0.0071^{* * *}$ & $0.0097^{* * *}$ & $0.0063^{* * *}$ \\
\hline & (5.94) & (8.05) & $(9.02)$ & (5.43) & $(8.04)$ \\
\hline \multirow[t]{2}{*}{ FOREIGN } & -0.0595 & -0.0122 & -0.0481 & -0.0369 & -0.0271 \\
\hline & $(-1.51)$ & $(-0.35)$ & $(-1.22)$ & $(-1.19)$ & $(-1.16)$ \\
\hline \multirow[t]{2}{*}{ LAROWN } & 0.0307 & 0.0215 & 0.0097 & 0.0040 & 0.0029 \\
\hline & $(0.89)$ & $(0.54)$ & $(0.32)$ & $(0.13)$ & $(0.13)$ \\
\hline \multirow[t]{2}{*}{$L N A F$} & -0.0013 & 0.0112 & 0.0023 & -0.0017 & -0.0044 \\
\hline & $(-0.18)$ & $(0.52)$ & $(0.12)$ & $(-0.08)$ & $(-0.36)$ \\
\hline \multirow[t]{2}{*}{ MtoB } & $-0.0410^{* * *}$ & $-0.0171^{* * *}$ & $-0.0137^{* * *}$ & $-0.0303^{* * *}$ & $-0.0221^{* * *}$ \\
\hline & $(-4.91)$ & $(-4.49)$ & $(-3.07)$ & $(-6.10)$ & $(-5.71)$ \\
\hline \multirow[t]{2}{*}{ BIG4 } & 0.0088 & -0.0012 & 0.0041 & 0.0160 * & 0.0002 \\
\hline & $(0.86)$ & $(-0.11)$ & $(0.41)$ & (1.91) & $(0.03)$ \\
\hline \multirow[t]{2}{*}{ KSE } & 0.0133 & $0.0548 * * *$ & $0.0357^{* * *}$ & $0.0304^{* * *}$ & $0.0169^{* *}$ \\
\hline & $(0.87)$ & (3.77) & (3.12) & $(2.77)$ & $(2.61)$ \\
\hline YEAR & Included & Included & Included & Included & Included \\
\hline INDUSTRY & Included & Included & Included & Included & Included \\
\hline Observations & 337 & 384 & 347 & 359 & 354 \\
\hline Adjusted $\mathrm{R}^{2}$ & 0.5037 & 0.4731 & 0.5129 & 0.5135 & 0.6203 \\
\hline
\end{tabular}

Notes: This table shows the results of the regressions of $E / P$ ratio on disclosure frequency using ICOE sample. To test the impact of information environment, I separate the sample using the level of firm size (SIZE) and the number of analyst following (LNAF). In Column (2) to (6) of Panel A, sample is divided into 5 (quintile) groups. Group 1 indicates the sample with bottom (smallest) quintile of firm size, and Group 5 indicates the sample with top (largest) quintile of firm size. In Panel B, Group 1 indicates the sample with bottom (smallest) quintile of analyst following, and Group 5 indicates the sample with top (largest) quintile of analyst following. Both year and industry dummies are considered in the regressions but not declared and the result using ICOE $A V G$ as a dependent variable is only reported for brevity. The results with other ICOEs are similar. The t-statistics (in parenthesis) are adjusted by using standard errors clustered on every firm. The symbols ***,**, and * refer to significant difference at the 1,5, 10 percent level (two-tailed), respectively. See Tables A1 and A2 of Appendix A for a description of the variables.

\subsubsection{Selection Bias in the ICOE Sample}

Firms with ICOE are not randomly distributed. As discussed earlier, measuring the ICOE requires future earnings per share, and analyst forecasts of future earnings are the most widely used proxy of expected earnings. The problem with the requirements of analyst forecast data is that these firms are likely to be systematically different from firms for which we cannot obtain forecast data. Therefore, firms for which we can obtain ICOE are inherently not free from the selection bias problem. To correct for the possible selection bias of the following analysis, I employ the two-stage procedure of Heckman [40]. In the first stage, I run a probit model to explain what determines the following of financial analysts to a certain firm. The dependent variable, DUM_FOLLOWING, is a dummy variable that takes 1 if the firm exists in ICOE sample and 0 otherwise. Following prior research, I choose the number of firms in the industry (NUM_IND) and earnings surprise (EARNINGS_SURPRISE) as determinants in the first stage model. The variable, NUM_IND, is used as a determinant because it is likely to attract more analysts if a firm belongs to a larger industry [41,42]. I also use EARNINGS_SURPRISE since prior studies show that analysts avoid following firms with highly volatile earnings [43]. The second stage of the model is the ICOE equation, which includes the correction factor (IMR, inverse Mill's ratio) computed in the probit model. 
Results are shown in Table 8. Column (1) provides the first stage results. Between the two determinants, the coefficient on NUM_IND is significant and positive, which is in line with the findings in prior literature. The second stage regression results are presented in Column (2). The coefficient of $I M R$ is significant, which indicates the existence of a selection bias. The coefficient of $F D$ in Column (2) still remains insignificant. The results of using Heckman's approach suggest that disclosure frequency is not associated with the cost of equity capital, measured as ICOEs, even after considering the self-selection problem.

Table 8. The Impact of Disclosure on the ICOE: Heckman Analysis.

\begin{tabular}{|c|c|c|}
\hline & (1) & (2) \\
\hline Variables & First Stage & Second Stage \\
\hline CONSTANT & $\begin{array}{c}-14.4337^{* * *} \\
(-21.67)\end{array}$ & $\begin{array}{c}0.0949 \\
(1.28)\end{array}$ \\
\hline NUM_IND & $\begin{array}{c}0.0047^{* * *} \\
(6.97)\end{array}$ & \\
\hline EARNINGS_SURPRISE & $\begin{array}{c}-0.0009 \\
(-0.43)\end{array}$ & \\
\hline$F D$ & $\begin{array}{c}0.0488^{* * *} \\
(7.40)\end{array}$ & $\begin{array}{c}0.0004 \\
(1.20)\end{array}$ \\
\hline LNVOLUME & $\begin{array}{c}0.0197 \\
(1.16)\end{array}$ & $\begin{array}{c}0.0010 \\
(0.95)\end{array}$ \\
\hline SIZE & $\begin{array}{c}0.4991^{* * *} \\
(18.70)\end{array}$ & $\begin{array}{c}-0.0044 \\
(-1.75)\end{array}$ \\
\hline LEV & $\begin{array}{c}-0.2220^{* * *} \\
(-6.18)\end{array}$ & $\begin{array}{c}0.0130^{* * *} \\
(5.92)\end{array}$ \\
\hline$R O A$ & $\begin{array}{c}0.0536^{* * *} \\
(13.60)\end{array}$ & $\begin{array}{c}0.0005 \\
(1.63)\end{array}$ \\
\hline BETA & & $\begin{array}{c}-0.0006 \\
(-0.17)\end{array}$ \\
\hline LNAF & & $\begin{array}{l}-0.0019 \\
(-1.54)\end{array}$ \\
\hline FOREIGN & $\begin{array}{c}1.5356^{* * *} \\
(7.53)\end{array}$ & $\begin{array}{c}0.0024 \\
(0.22)\end{array}$ \\
\hline LAROWN & $\begin{array}{c}-0.9512 * * * \\
(-5.59)\end{array}$ & $\begin{array}{c}0.0034 \\
(0.35)\end{array}$ \\
\hline BIG4 & $\begin{array}{c}0.1304^{* *} \\
(2.49)\end{array}$ & $\begin{array}{c}0.0062 * * \\
(2.20)\end{array}$ \\
\hline MtoB & $\begin{array}{c}0.1413^{* * *} \\
(7.13)\end{array}$ & $\begin{array}{c}-0.0046^{* * *} \\
(-4.14)\end{array}$ \\
\hline KSE & $\begin{array}{c}-0.2448 * * * \\
(-3.73)\end{array}$ & $\begin{array}{c}-0.0016 \\
(-0.46)\end{array}$ \\
\hline DISPERSION & & $\begin{array}{c}0.2580^{* * *} \\
(5.35)\end{array}$ \\
\hline BIAS & & $\begin{array}{c}-0.0582 * * * \\
(-5.59)\end{array}$ \\
\hline$I C O E_{-} A V G I N D$ & & $\begin{array}{c}0.7166^{* * *} \\
(11.96)\end{array}$ \\
\hline$I M R$ & & $\begin{array}{c}0.0204^{* * *} \\
(2.81)\end{array}$ \\
\hline YEAR & Included & Included \\
\hline INDUSTRY & Included & Included \\
\hline Observations & 7470 & 1116 \\
\hline Pseudo $R^{2}$ & 0.3469 & \\
\hline Adjusted $R^{2}$ & & 0.5019 \\
\hline
\end{tabular}

Notes: This figure reports the results of Heckman's [40] two-stage procedure. The first stage is a probit model, where the dummy variable (the dependent variable) equals 1 if a firm is followed by analysts and 0 otherwise (DUM_FOLLOWING). NUM_IND (the number of firms in the industry) and EARNINGS_SURPRISE (the absolute value of the difference between the current earnings per share and the lagged earnings per share, scaled by the lagged earnings per share) are used as determinants of analyst following. IMR (inverse Mill's ratio) is the correction term used in the second stage regression. Both year and industry dummies are considered in the regressions but not declared and the result using $I C O E_{-} A V G$ as a dependent variable is only reported for brevity. The results with other ICOEs are similar. The t-statistics (in parenthesis) are adjusted by using standard errors clustered on every firm. The symbols ${ }^{* * *},{ }^{* *}$, and ${ }^{*}$ refer to significant difference at the 1, 5, 10 percent level (two-tailed), respectively. See Tables A1 and A2 of Appendix A for a description of the variables. 


\section{Conclusions}

Whether disclosure policy affects capital market is an essential question in accounting. Theories suggest the existence of a negative relationship between disclosure and cost of capital. Public disclosure makes collecting private information harder and costly, and hence, investors with private information decrease. It also mitigates the potential advantage of using private information. These two effects reduce required rate of return or cost of equity capital [2]. Disclosure has a direct impact as well in that it can help investors to more confidently estimate a firm's risk factor or parameter which reduces the cost of capital, without linkage of liquidity [18]. Therefore, disclosure policy contributes to improve sustainable corporate information environment and to sustain a profitable business, since lowering costs of capital through public disclosure activities is a fundamental issue of the company.

While theoretical studies generally support a negative relation between disclosure and the cost of capital, the empirical findings on the relationship between disclosure and costs of capital is not unambiguous yet $[8,9,25,44]$. One of the limitations in prior studies is that proxies for disclosure have measurement errors. The AIMR database is limited to large firms and it is unclear whether the panels of AIMR take the ranking seriously. Self-constructed measures of disclosure involve judgments of the researcher and typically rely on annual reports or similar public documents [45]. Furthermore, while the majority of studies investigating the impact of disclosure focus on the case of the U.S. market, Hail [46] and Leuz and Verrecchia [6] suggest a stronger relationship between disclosure and cost of capital would take place in countries with weak institutional backgrounds. These could be potential reasons for the ambiguous empirical results in disclosure studies.

This study investigates the impact of disclosure on cost of capital by using Korean data. Reg FD mandates to disseminate full and prompt information to all information users. The unique feature of the regulation in Korea is that the disclosure channel is unified to one electronic disclosure system. Listed companies are subject to the enforcement and they are punished for violations of this rule. Besides, Korean Reg FD covers all the material voluntary information, data are comprehensive and highly credible. Using the data from 2004 to 2013, I find a negative relationship between disclosure and the cost of equity capital proxied by the E/P ratio. However, when I use ICOE measures, there is not a significant relationship between frequencies of disclosures and cost of equity capital. The result should be carefully interpreted because analysts follow only relatively large firms in Korea, and considering the lack of analyst forecast data, the sample selection problem could distort the empirical results on the relationship between disclosure and ICOE. To reconcile the results, I separate the sample by firm size and analyst followings and find that the effect of disclosure is stronger for smaller size and lower analyst following firms in $E / P$ ratio sample. However, the effect of disclosure on $E / P$ ratio disappears when I use ICOE sample. It suggests that the insignificant relation between disclosure and cost of capital can be attributable to the better information environment of ICOE sample. This seems to provide evidence that disclosure reduces cost of capital only when the information environment is poor [8].

Although this paper provides partial evidence of the negative impact of disclosure on cost of capital, it contributes to the prior literature in several ways. First, few studies have investigated the relationship between disclosure quality and its capital market consequences in comprehensive ways using Korean data. I use the measure of disclosure frequency which is highly accurate and covers all listed firms. This overcomes the limitations of using self-constructed measures. Second, the findings in this study have policy implications for managers, regulators, and investors. This study provides an empirical evidence for the benefits of adopting Reg FD by showing cross-sectional variations of the cost of capital, followed by the level of disclosure. Third, this paper presents the grounds for an argument that researchers consider the effect of information environment surrounding a firm in examining the consequences of disclosure activity.

This study also has several limitations. First, even though I tried to analyze as many companies as possible to reduce sampling bias, it is necessary to extend the sample period. Second, it is also necessary to use more various measures to validate the results of this paper; for example, the use of 
categorized fair disclosure will deepen the understanding of different information content's impact on capital market. Finally, this paper does not address the effect of fair disclosure on several aspects other than the cost of equity. Future research can extend this study to cost of debt or weighted average cost of capital.

Funding: This research received no external funding.

Acknowledgments: The author is very grateful for the helpful comments from the guest editor and three anonymous reviewers.

Conflicts of Interest: The author declares no conflict of interest.

\section{Appendix A}

Table A1. Estimating ICOE.

\begin{tabular}{|c|c|}
\hline \multicolumn{2}{|r|}{ Panel A. Definitions of Variables } \\
\hline Variables & Definitions \\
\hline $\begin{array}{l}P_{i t} \\
b p s_{i t} \\
d p s_{i t} \\
e p s_{i t} \\
E_{t}[\cdot]\end{array}$ & $\begin{array}{l}\text { Market price of common shares for firm } i \text { at time } t \\
\text { Book value per share from the most recent available financial statement at time } t \\
\text { Expected future dividends per share at time } t \\
\text { Mean or median earnings forecasts per share by financial analysts at time } t \\
\text { Expectation based on information at time } t\end{array}$ \\
\hline \multicolumn{2}{|c|}{ Panel B. Estimates of ICOE following Gordon and Mohanram [34]: ICOE_GM } \\
\hline $\begin{array}{l}\text { Formula and } \\
\text { assumptions }\end{array}$ & $\begin{array}{l}P_{i t}=\frac{e p s_{i t+1}}{r}+\frac{e p s_{i t+1} \times\left(\frac{e p s_{i t+2}-e p s_{i t+1}}{e p s i t+1}+\frac{r \times d p s_{i t+1}}{e p s_{i t+1}}-r\right)}{r \times((1+r)-\gamma)} \\
\text { where } z_{t+1}=\gamma \times z_{t}, t=1,2, \cdots \text { where } 1 \leq \gamma \leq(1+r) \text { and } z_{1}>0, \gamma-1 \text { is a } \\
\text { perpetual growth rate, } r=A+\sqrt{A^{2}+\frac{e p s_{i t+1}}{P_{i t}}\left(g_{2}-(\gamma-1)\right)} \text { where } \\
A \equiv \frac{1}{2}\left((\gamma-1)+\frac{d p s_{i t+1}}{P_{i t}}\right), \text { and } g_{2} \text { is a short-term growth rate }\left(=\frac{e p s_{i t+2}-e p s_{i t+1}}{e p s_{i t+1}}\right) \text {. } \\
\text { Gordon and Mohanram [34] estimate the ICOE based on the Ohlson and } \\
\text { Juettner-Nauroth (OJ) [36] model. The OJ model is based on the dividend } \\
\text { discount model in terms of deriving changes in abnormal earnings that exceeds } \\
\text { the return on net reinvestment. In specific, this model uses the short-term } \\
\text { growth rate } \frac{e p s_{i t+2}-e p s_{i t+1}}{e p s_{i t+1}} \text { without a clean surplus relation in addition to the } \\
\text { single constant perpetual growth rate } \gamma-1 \text {. The short-term growth rate is } \\
\text { assumed to converge to the perpetual growth rate. It requires a positive change } \\
\text { in forecast earnings to yield a numerical solution and explicitly requires only } \\
\text { one dividend forecast, whereas the RIV model requires more forecasts and the } \\
\text { assumption of a clean surplus relation. Dividends are set to equal a constant } \\
\text { fraction of forecast earnings. In implementing the OJ model, Gode and } \\
\text { Mohanram [34] use the forecast average of two-year and five-year growth as the } \\
\text { short-term growth rate. It is assumed that all future payout ratios to be equal to } \\
\text { the current payout ratio. Payout ratio is calculated as follows: Positive current } \\
\text { earnings implies that current dividends to be devided by current earnings. } \\
\text { Negative current earnings implies that current dividends to be devided by } \\
\text { normal earnings, which are assumed to be 6\% of total assets. } \\
\text { To estimate the risk premium with Korean data, this study follows Hwang et al. } \\
\text { [37]. They assume the growth rate as imposed in subsequent two-year forecasts, } \\
\text { as analysts do not explicitly provide five-year long-term growth data for Korea. } \\
\text { The yield on a three-year Treasury bond in Korea is used as the risk-free rate. }\end{array}$ \\
\hline
\end{tabular}


Table A1. Cont.

Panel C. Estimates of ICOE following Easton [35]: ICOE_EST

$P_{i t}=\frac{e p s_{i t+2}+r \times d p s_{i t+1}-e p s_{i t+1}}{r^{2}}$

where eps $s_{i t+2} \geq$ eps $_{i t+1}>0$.

Easton [35] provides the modified price-earnings growth (MPEG) model, which is a special case of the OJ model. The MPEG model assumes that the expected

Formula and abnormal growth in earnings in the following period is considered to be an assumptions unbiased estimate of abnormal growth in earnings over all subsequent periods $(\gamma-1=0)$. In addition, it requires positive changes in forecast earnings to provide a numerical solution. Except for the abnormal growth rate being zero, there is no difference between the OJ model and the MPEG model in the analysis.

Panel D. Estimates of ICOE following Claus and Thomas [32]: ICOE_CT

$P_{i t}=b p s_{i t}+\sum_{\tau=1}^{5} \frac{\left(R O E_{i t+\tau}-r\right) \times b p s_{i t+\tau-1}}{(1+r)^{\tau}}+\frac{\left(R O E_{i t+5}-r\right) \times b p s_{i t+4} \times(1+g)}{(r-g) \times(1+r)^{5}}$

where $R O E_{i t+\tau}=\frac{e p s_{i t+\tau}}{b p s_{i t+\tau-1}}$ and $e p s_{i t+\tau}=e p s_{i t+2} \times\left(1+l t g_{i}\right)^{\tau-2}$ for $\forall \tau>2$, ltg $g_{i}$ is the expected earnings growth over the next five years, $g$ is a constant risk-free rate, which represents the expected inflation rate $\left(r_{f}-3 \%\right)$, and $r_{f}$ is a risk-free rate.

Formula and This model assumes that growth in residual income over a forecasted horizon assumptions equals the risk-free rate minus 3\%. The current stock price is set to equal the current book value of equity plus the present value of future expected residual income series, where the a charge for the cost of equity capital is subtracted from forecast accounting earnings. Claus and Thomas [32] consider the actual book values and analysts' earnings forecasts over maximum five years and assume earnings after year $t+5$ to increase at the inflation rate. The real inflation rate is considered in the calculation when the data of forecasted earnings are not available up to five years.

Panel E. Estimates of ICOE following Gebahrdt et al. [33]: ICOE_GLS

Formula and assumptions

$$
\begin{aligned}
P_{i t} & =b p s_{i t}+\frac{\left(R O E_{i t+1}-r\right) \times b p s_{i t}}{(1+r)}+\frac{\left(R O E_{i t+2}-r\right) \times b p s_{i t+1}}{(1+r)} \\
& +\sum_{\tau=3}^{T-1} \frac{\left(R O E_{i t+\tau}-r\right) \times b p s_{i t+\tau-1}}{(1+r)^{\tau}}+\frac{\left(R O E_{i t+T}-r\right) \times b p s_{i t+T-1}}{r \times(1+r)^{T-1}}
\end{aligned}
$$

where $R O E_{i t+\tau}=\frac{e p s_{i t+\tau}}{b p s_{i t+\tau-1}}$ for $\tau=1,2$ and $R O E_{i t+\tau}=R O E_{i t+\tau-1}-$ fade $\forall \tau>2$, fade $=\frac{\left(R O E_{i t-2}-H I R O E_{t}\right)}{9}, b p s_{i t+\tau-1}+e p s_{i t+\tau}-d p s_{i t+\tau}$, and $d p s_{i t+\tau}=e p s_{i t+\tau} \times k$. Gebhardt et al. [33] use a two-stage approach to infer the costs of equity capital. First, they explicitly use the forecasts of the mean one-and two-year-ahead earnings and the long-term growth rate to compute a three-year-ahead earnings forecast. These earnings forecasts and the dividend payout ratio are used in forecasting the future book values and returns on earnings (ROEs) by applying clean surplus accounting. Second, they forecast earnings beyond year three by mean reverting the $R O E_{t+3}$ to the median industry $R O E$ by the period $t+T$. The industry $R O E$ is a moving median of past ROEs from all firms in the same industry. Beyond the forecast horizon $(\mathrm{T}=12)$, they assume that the final term $\left(R O E_{12}-r\right) \times b p s_{11}$ remains constant in perpetuity. They group all stocks into 48 industries and calculate the target industry ROE (moving median of past ROEs among the same industry). Loss firms are excluded, based on the assumption that profitable firms can reflect long-term industry equilibrium rate of returns in a better way. Following Hwang et al. [37], I choose the growth rate between $e p s_{1}$ and $e p s_{2}$ to be a long-term growth rate in computing a three-year-ahead earnings forecast, and group all stocks according to the two-digit Korean Standard Industrial Classification (KSIC) to compute the target industry ROE in this study. I exclude industries that have fewer than five firm year observations. 
Table A2. Variables specification and description

\begin{tabular}{|c|c|c|}
\hline Variables & Symbol & Variable Description \\
\hline Cost of Equity Capital & $E / P$ & Earnings to price ratio \\
\hline $\begin{array}{l}\text { Implied Cost of Equity } \\
\text { Capital }\end{array}$ & $I C O E_{-G M}$ & $\begin{array}{l}\text { Estimated risk premium minus the risk free rate } \\
\text { by Gode and Mohanram [34] }\end{array}$ \\
\hline $\begin{array}{l}\text { Implied Cost of Equity } \\
\text { Capital }\end{array}$ & $I C O E_{-} E S T$ & $\begin{array}{l}\text { Estimated risk premium minus the risk free rate } \\
\text { by Easton [35] }\end{array}$ \\
\hline $\begin{array}{l}\text { Implied Cost of Equity } \\
\text { Capital }\end{array}$ & $I C O E_{-} C T$ & $\begin{array}{l}\text { Estimated risk premium minus the risk free rate } \\
\text { by Claus and Thomas [32] }\end{array}$ \\
\hline $\begin{array}{l}\text { Implied Cost of Equity } \\
\text { Capital }\end{array}$ & $I C O E_{-} G L S$ & $\begin{array}{l}\text { Estimated risk premium minus the risk free rate } \\
\text { by Gebhardt et al. [33] }\end{array}$ \\
\hline $\begin{array}{l}\text { Implied Cost of Equity } \\
\text { Capital }\end{array}$ & $I C O E_{-} A V G$ & Average of the four ICOE measures above \\
\hline Disclosure Frequency & $F D$ & $\begin{array}{l}\text { Number of issued fair disclosures during } \\
\text { calendar year } t\end{array}$ \\
\hline Market Liquidity & LNVOLUME & $\begin{array}{l}\text { Natural log of the average of daily trading } \\
\text { volume during calendar year } t\end{array}$ \\
\hline Firm Size & SIZE & $\begin{array}{l}\text { Natural log of market capitalization at the end of } \\
\text { the year }\end{array}$ \\
\hline Financial Leverage & $L E V$ & $\begin{array}{l}\text { Sum of short- and long-term debt scaled by total } \\
\text { assets }\end{array}$ \\
\hline Profitability & $R O A$ & $\begin{array}{l}\text { Return on assets (net income scaled by total } \\
\text { assets) }\end{array}$ \\
\hline Analyst forecasts & LNAF & $\begin{array}{l}\text { Natural log of the number of analyst forecasts } \\
\text { plus one }\end{array}$ \\
\hline $\begin{array}{l}\text { Size of Foreign } \\
\text { Ownership }\end{array}$ & FOREIGN & $\begin{array}{l}\text { Stock ownership of foreign shareholders in the } \\
\text { beginning of the year }\end{array}$ \\
\hline $\begin{array}{l}\text { Size of Largest } \\
\text { Shareholding }\end{array}$ & LAROWN & $\begin{array}{l}\text { Stock ownership of the largest shareholder in the } \\
\text { previous year }\end{array}$ \\
\hline Big 4 Auditor & BIG4 & $\begin{array}{l}\text { Dummy variable that equals one if a firm is } \\
\text { audited by one of the Big } 4 \text { auditors and } 0 \\
\text { otherwise }\end{array}$ \\
\hline Market to Book ratio & $M t o B$ & $\begin{array}{l}\text { Ratio of the market value of equity to the book } \\
\text { value of equity }\end{array}$ \\
\hline Market Indicator & KSE & $\begin{array}{l}\text { Dummy variable which equals one if a firm is } \\
\text { listed in the Korea Composite Stock Price Index } \\
\text { (KOSPI) and } 0 \text { otherwise (KOSDAQ) }\end{array}$ \\
\hline $\begin{array}{l}\text { Properties of Analyst } \\
\text { Forecasts }\end{array}$ & DISPERSION & $\begin{array}{l}\text { Standard deviation of one-year-ahead analyst } \\
\text { earnings forecasts scaled by the stock price }\end{array}$ \\
\hline $\begin{array}{l}\text { Properties of Analyst } \\
\text { Forecasts }\end{array}$ & $B I A S$ & $\begin{array}{l}\text { Signed forecast error calculated by the difference } \\
\text { between actual earnings per share and the } \\
\text { forecast consensus for year t earnings, which is } \\
\text { delated by the stock price at year } t-1\end{array}$ \\
\hline $\begin{array}{l}\text { Implied Cost of Equity } \\
\text { Capital }\end{array}$ & $I C O E_{A} A V G I N D$ & Average of industry estimated risk premium \\
\hline Firm Risk & BETA & $\begin{array}{l}\text { Market beta estimated for each stock at the end of } \\
\text { June of every year, using the stock's previous } 60 \\
\text { monthly returns (12-month minimum) }\end{array}$ \\
\hline Fixed Effects & YrDum & Year dummy variable \\
\hline Fixed Effects & IndDum & Industry dummy variable \\
\hline
\end{tabular}




\section{References}

1. Dye, R.A. An evaluation of "essays on disclosure" and the disclosure literature in accounting. J. Account. Econ. 2001, 32, 181-235. [CrossRef]

2. Verrecchia, R.E. Essays on disclosure. J. Account. Econ. 2001, 32, 97-180. [CrossRef]

3. Easley, D.; O'Hara, M. Information and the cost of capital. J. Financ. 2004, 59, 1553-1583. [CrossRef]

4. Ok, Y.; Kim, J. Which corporate social responsibility performance affects the costs of equity? Evidence from Korea. Sustainability 2019, 11, 2947. [CrossRef]

5. Shim, H. Disclosure activity and the stock market liquidity under the regulation fair disclosure: A comparison between SMEs and large firms. J. Small Bus. Innov. 2015, 18, 67-85.

6. Leuz, C.; Verrecchia, R.E. The economic consequences of increased disclosure. J. Account. Res. 2000, 38, 91-124. [CrossRef]

7. La Porta, R.; Lopez-de-Silanes, F.; Shleifer, A.; Vishny, R. Legal determinants of external finance. J. Financ. 1997, 52, 471-517. [CrossRef]

8. Botosan, C.A. Disclosure level and the cost of equity capital. Account. Rev. 1997, 72, 323-349.

9. Botosan, C.A.; Plumlee, M.A. A re-examination of disclosure level and the expected cost of equity capital. J. Account. Res. 2002, 40, 21-40. [CrossRef]

10. Akerlof, G.A. The market for "lemons": Quality uncertainty and the market mechanism. Q. J. Econ. 1970, 84, 488-500. [CrossRef]

11. Jensen, M.C.; Meckling, W.H. Theory of the firm: Managerial behavior, agency costs and ownership structure. J. Financ. Econ. 1976, 3, 305-360. [CrossRef]

12. Botosan, C.A. Disclosure and the cost of capital: What do we know? Account. Bus. Res. 2006, 36, 31-40. [CrossRef]

13. Easley, D.; Hvidkjaer, S.; O'Hara, M. Is information risk a determinant of asset returns? J. Financ. 2002, 57, 2185-2222. [CrossRef]

14. Barry, C.; Brown, S. Differential information and security market equilibrium. J. Financ. Quant. Anal. 1985, 20, 407-422. [CrossRef]

15. Brown, S. The effect of estimation risk on capital market equilibrium. J. Financ. Quant. Anal. 1979, 15, $215-220$. [CrossRef]

16. Coles, J.; Loewenstein, U.; Suay, J. On equilibrium pricing under parameter uncertainty. J. Financ. Quant. Anal. 1995, 30, 347-364. [CrossRef]

17. Leuz, C.; Wysocki, P.D. Economic Consequences of Financial Reporting and Disclosure Regulation: A Review and Suggestions for Future Research; Working Paper; University of Chicago: Chicago, IL, USA, 2008.

18. Lambert, R.; Leuz, C.; Verrecchia, R.E. Accounting information, disclosure, and the cost of capital. J. Account. Res. 2007, 45, 385-420. [CrossRef]

19. Lambert, R.; Leuz, C.; Verrecchia, R.E. Information asymmetry, information precision, and the cost of capital. Rev. Financ. 2011, 16, 1-29. [CrossRef]

20. Li, L.; Yang, Y.H.; Tang, D.L. Carbon information disclosure of enterprises and their value creation through market liquidity and cost of equity capital. J. Ind. Eng. Manag. 2015, 8, 137-151. [CrossRef]

21. Li, L.; Liu, Q.; Tang, D.L.; Xiong, J.C. Media reporting, carbon information disclosure and the cost of equity financing: Evidence from China. Environ. Sci. Pollut. Res. 2017, 24, 9447-9459. [CrossRef]

22. Li, L.; Liu, Q.; Wang, J.; Hong, X. Carbon information disclosure, marketization, and cost of equity financing. Int. J. Environ. Res. Public Health 2019, 16, 150. [CrossRef] [PubMed]

23. Fonseka, M.; Rajapakse, T.; Tian, G.L. The effects of environmental information disclosure and energy types on the cost of equity: Evidence from the energy industry in China. Abacus 2019, 55, 362-410. [CrossRef]

24. Graham, J.R.; Harvey, C.R.; Rajgopal, S. The economic implications of corporate financial reporting. J. Account. Econ. 2005, 40, 3-73. [CrossRef]

25. Healy, P.M.; Hutton, A.; Palepu, K.G. Stock performance and intermediation changes surrounding sustained increases in disclosure. Contemp. Account. Res. 1999, 16, 485-520. [CrossRef]

26. Fu, R.; Kraft, A.; Zhang, H. Financial reporting frequency, information asymmetry, and the cost of equity. J. Account. Econ. 2012, 54, 132-149. [CrossRef]

27. Van Buskirk, A. Disclosure frequency and information asymmetry. Rev. Quant. Financ. Account. 2012, 38, 411-440. [CrossRef] 
28. Botosan, C.A.; Plumlee, M.A.; Wen, H. The relation between expected returns, realized returns, and firm risk characteristics. Contemp. Account. Res. 2011, 28, 1085-1122. [CrossRef]

29. Dechow, P.; Dichev, I. The quality of accruals and earnings: The role of accrual estimation errors. Account. Rev. 2002, 77, 35-59. [CrossRef]

30. Liu, J.; Nissim, D.; Thomas, J. Equity valuation using multiples. J. Account. Res. 2002, 40, 135-172. [CrossRef]

31. Francis, J.; LaFond, R.; Olsson, P.; Schipper, K. The market pricing of accruals quality. J. Account. Econ. 2005, 39, 295-327. [CrossRef]

32. Claus, J.; Thomas, J. Equity premia as low as three percent? Evidence from analysts' earnings forecasts for domestic and international stock markets. J. Financ. 2001, 56, 1629-1666.

33. Gebhardt, W.R.; Lee, C.M.C.; Swaminathan, B. Toward an implied cost of capital. J. Account. Res. 2001, 39, 135-176. [CrossRef]

34. Gode, D.; Mohanram, P. Inferring the cost of capital using the ohlson-juettner model. Rev. Account. Stud. 2003, 8, 399-431. [CrossRef]

35. Easton, P. PE ratios, PEG ratios, and estimating the implied expected rate of return on equity capital. Account. Rev. 2004, 79, 73-96. [CrossRef]

36. Ohlson, J.; Juettner-Nauroth, B. Expected EPS and EPS growth as determinants of value. Rev. Account. Stud. 2005, 10, 349-365. [CrossRef]

37. Hwang, L.S.; Lee, W.J.; Lim, S.Y. Korean evidence on the implied cost of equity. Korean Account. Rev. 2008, 33, 97-125.

38. Fama, E.F.; French, K.R. The cross-section of expected stock returns. J. Financ. 1992, 47, 427-465. [CrossRef]

39. Chow, G.C. Tests of equality between sets of coefficients in two linear regressions. Econometrica 1960, 52, 211-222. [CrossRef]

40. Heckman, J.J. Sample selection bias as a specification error. Econometrica 1979, 47, 153-161. [CrossRef]

41. Rajan, R.; Servaes, H. Analyst following of initial public offerings. J. Financ. 1997, 52, 507-529. [CrossRef]

42. Boubaker, S.; Labégorre, F. Ownership structure, corporate governance and analyst following: A study of french listed firms. J. Bank. Financ. 2008, 32, 961-976. [CrossRef]

43. Lang, M.H.; Lundholm, R.J. Corporate disclosure policy and analyst behavior. Account. Rev. 1996, 71, 467-492.

44. Welker, M. Disclosure policy, information asymmetry, and liquidity in equity markets. Contemp. Account. Res. 1995, 11, 801-882. [CrossRef]

45. Healy, P.M.; Palepu, K.G. Information asymmetry, corporate disclosure, and the capital markets: A review of the empirical disclosure literature. J. Account. Econ. 2001, 31, 405-440. [CrossRef]

46. Hail, L. The impact of voluntary corporate disclosures on the ex-ante cost of capital for swiss firms. Eur. Account. Rev. 2002, 11, 741-773. [CrossRef]

(C) 2020 by the author. Licensee MDPI, Basel, Switzerland. This article is an open access article distributed under the terms and conditions of the Creative Commons Attribution (CC BY) license (http://creativecommons.org/licenses/by/4.0/). 